\title{
Improving the sustainability of granular iron/pumice systems for water
}

\section{treatment}

Stefania Bilardi ${ }^{a}$, Paolo S. Calabrò ${ }^{\mathrm{a}}$, Sabine Caré ${ }^{\mathrm{b}}$, Nicola Moraci ${ }^{\mathrm{a}}$, Chicgoua Noubactep ${ }^{\mathrm{c}, \mathrm{d}, *}$

${ }^{a}$ Università degli Studi Mediterranea di Reggio Calabria, MECMAT, Mechanics and Materials Department, Faculty of Engineering, Via Graziella, loc. Feo di Vito, 89122 Reggio Calabria, Italy.

${ }^{\mathrm{b}}$ Université Paris-Est, Laboratoire Navier (UMR 8205), CNRS, ENPC, IFSTTAR, F-77455 Marne-la-Vallée, France;

${ }^{\mathrm{c} A n g e w a n d t e ~ G e o l o g i e, ~ U n i v e r s i t a ̈ t ~ G o ̈ t t i n g e n, ~ G o l d s c h m i d t s t r a ß e ~ 3, ~ D-37077, ~ G o ̈ t t i n g e n, ~ G e r m a n y . ~}$

${ }^{\mathrm{d}}$ Kultur und Nachhaltige Entwicklung CDD e.V., Postfach 1502, D-37005 Göttingen, Germany

* e-mail: cnoubac@gwdg.de; Tel. +49 55139 3191, Fax. +49 551399379.

\section{Abstract}

Metallic iron $\left(\mathrm{Fe}^{0}\right)$ is currently used in subsurface and above-ground water filtration systems on a pragmatic basis. Recent theoretical studies have indicated that, to be sustainable, such systems should not contain more than $60 \% \mathrm{Fe}^{0}$ (vol/vol). The prediction was already validated in a $\mathrm{Fe}^{0} / \mathrm{sand}$ system using methylene blue as an operational tracer. The present work is the first attempt to experimentally verify the new concept using pumice particles. A well-characterized pumice sample is used as operational supporting material and is mixed with $200 \mathrm{~g}$ of a granular $\mathrm{Fe}^{0}$, in volumetric proportions, varying from 0 to $100 \%$. The resulting column systems are characterized (i) by the time dependent evolution of their hydraulic conductivity and (ii) for their efficiency for the removal of $\mathrm{Cu}^{\mathrm{II}}, \mathrm{Ni}^{\mathrm{II}}$, and $\mathrm{Zn}^{\mathrm{II}}$ from a three-contaminants-solution (about $0.30 \mathrm{M}$ of each metal). Test results showed a clear sustainability of the long term hydraulic conductivity with decreasing $\mathrm{Fe}^{0} / \mathrm{pumice}$ ratio. In fact, the pure $\mathrm{Fe}^{0}$ system clogged after 17 days, while the $25 \% \mathrm{Fe}^{0}$ system could operate for 36 days. The experimental data confirmed the view that well-designed $\mathrm{Fe}^{0} \mathrm{PRBs}$ may be successful at removing both reducible and irreducible metal species.

\footnotetext{
* Corresponding author: Tel. +49 55139 3191, Fax. +49 551 399379; E-mail: cnoubac@gwdg.de.
} 
1 Keywords: Column study, Hydraulic conductivity, Reactive walls, Pumice, Zerovalent iron.

2

\section{$1 \quad$ Introduction}

Filter materials for water treatment are ideally used in small quantities. The high required affinity of used aggregates for efficient water treatment is not always readily available in natural materials. On the other hand, efficient filters should be designed to make the best use of these latter with the minimum of processing (Smith et al., 2001). Alternatively, readily available natural materials (e.g. anthracite, gravel, pumice, sand) may be mixed to low cost synthetic aggregates/materials (activated carbon, blast furnace slag, metallic iron) for improving the performance of the resulting water treatment systems. The key properties determining the permeability, the stability and the longevity (sustainability) of granular filters include porosity/texture of used particles, particle size, particle shape and particle size distribution or material sorting (Haarhoff and Vessal, 2010; Kubare and Haarhoff, 2010; Miyajima, 2012; Btatkeu et al., 2013; Caré et al., 2013). Two key interrelated properties required for a sustainable filter include: (i) high permeability combined with resistance to internal erosion of fines and (ii) low susceptibility to chemical attack (prerequisite 1).

Granular metallic iron $\left(\mathrm{Fe}^{0}\right)$, as currently used in water treatment, is a reactive material and its oxidative dissolution by water is a volumetric expansive process (Pilling and Bedworth, 1923; Caré et al., 2008). This means that $\mathrm{Fe}^{0}$ is highly susceptible to chemical attack and the products of this chemical reaction are fines/precipitates (iron hydroxides and oxides). In other words, 'prerequisite $1^{\prime}$ is not satisfied as the sustainability of $\mathrm{Fe}^{0}$ filters is impaired by the same properties making $\mathrm{Fe}^{0}$ an attractive material: the chemical reactivity of iron (Liu et al. 2013). However, without considering these key properties, $\mathrm{Fe}^{0}$ permeable reactive barriers $\left(\mathrm{Fe}^{0} \mathrm{PRBs}\right.$ ) have become an established technology for the treatment of contaminated groundwater (O'Hannesin and Gillham, 1998; Li et al., 2006; Li and Benson, 2010; Comba et al., 2011; Gheju, 2011; Ruhl et al., 2012). Currently, about $180 \mathrm{Fe}^{0}$ PRBs have been installed worldwide (ITRC, 2011). 
1 The fundamental mechanisms of contaminant removal in $\mathrm{Fe}^{0}$ filtration systems are adsorption, co-

2 precipitation and adsorptive size-exclusion (Noubactep, 2008; 2010; 2011). Contaminant removal

3 also implies iron corrosion (Lavine et el., 2001; You et al., 2005; Jiao et al., 2009; Ghauch et al.,

4 2011; Gheju and Balcu 2011). Therefore, due to the volumetric expansive nature of this process

5 ('prerequisite 1'), the remediation of contaminated groundwater necessarily results in the gradual

6 clogging of the $\mathrm{Fe}^{0} \mathrm{PRB}$, and thus in the deterioration of the permeable barrier hydraulic

7 conductivity (permeability loss) over time (Zhang and Gillham, 2005; Courcelles et al., 2011;

8 Knowles et al., 2011; Jeen et al., 2012; Miyajima, 2012; Noubactep, 2013a).

9 The gradual clogging (permeability loss) of $\mathrm{Fe}^{0}$ filtration systems has several origins: (i) biological

10 activities like biofilm growth or biocorrosion, (ii) chemical processes like (hydr)oxide or calcite

11 precipitation, (iii) physical processes allowing the retention of fine particles in the PRB pores, and

12 (iv) production and accumulation of gases (mainly $\mathrm{H}_{2}$ ). Pores clogging could generate a decrease in

13 treatment performance and the bypass of untreated contaminated groundwater (Courcelles et al.,

14 2011; Knowles et al., 2011; Jeen et al., 2012). Therefore, PRBs clogging issues will require cost-

15 intensive reactive material substitution, if satisfactory operational performance has to be

16 maintained. The present work is focused on the characterization of PRB clogging due to pore filling

17 by in-situ generated iron corrosion products neglecting the other possible phenomena that could

18 contribute to permeability reduction (i.e. gas retention, biocorrosion, biofouling) (Henderson and

19 Demond, 2011; Caré et al., 2012; Noubactep, 2013a).

20 The objective of the present work is to characterize the efficiency of $\mathrm{Fe}^{0} /$ pumice granular

21 mixtures for contaminant removal in column experiments containing 0 to $100 \% \mathrm{Fe}^{0}$ (vol/vol). $\mathrm{Fe}^{0}$

22 is admixed to a well-characterized pumice specimen (Moraci and Calabrò, 2010; Calabrò et al.,

23 2011; Bilardi et al., 2013a), in different volumetric ratios. The model oxic solution (about $8 \mathrm{mg} / \mathrm{L}$

$24 \mathrm{O}_{2}$ ) contained about $0.30 \mathrm{M}$ of $\mathrm{Cu}^{\mathrm{II}}, \mathrm{Ni}^{\mathrm{II}}$, and $\mathrm{Zn}^{\mathrm{II}}$. The evolution of the systems is characterized by 
1 determining the (i) extent of contaminant removal (or retention), and (ii) variation of hydraulic

2 conductivity.

\section{$3 \quad 2 \quad$ Materials and methods}

\section{$4 \quad 2.1 \quad$ Chemicals}

5 Copper(II) nitrate hydrate (purity 99.999), nickel(II) nitrate hexahydrate (purity 99.999) and zinc(II)

6 nitrate hexahydrate (purity 99.000) were obtained from Sigma-Aldrich. The three heavy metals are

7 used for their different affinity to iron oxides (Wang and Qin, 2007; Moreira and Alleoni, 2010;

8 Vodyanitskii, 2010). In addition, a survey of the electrode potential $\left(\mathrm{E}^{0}\right)$ of involved couples

9 indicated differential redox behaviours. In fact, $\mathrm{Zn}^{\mathrm{II}}\left(\mathrm{E}^{0}=-0.763 \mathrm{~V}\right)$ can not be reduced by $\mathrm{Fe}^{0}\left(\mathrm{E}^{0}=\right.$

$10-0.440 \mathrm{~V})$ while $\mathrm{Cu}\left(\mathrm{E}^{0}=0.337 \mathrm{~V}\right)$ is readily reduced. The electrode potential of $\mathrm{Ni}\left(\mathrm{E}^{0}=-0.250 \mathrm{~V}\right)$

11 is relatively close to that of $\mathrm{Fe}\left(\Delta \mathrm{E}^{0}=0.19 \mathrm{~V}\right)$ such that quantitative reduction can not be expected.

\section{$12 \quad 2.2 \quad$ Solid materials}

13 Pumice: the used pumice originates from Lipari (Aeolian Islands, Sicily - Italy); its mineralogical 14 composition was determined as follows: $\mathrm{SiO}_{2}: 71.75 \% ; \mathrm{Al}_{2} \mathrm{O}_{3}: 12.33 \% ; \mathrm{K}_{2} \mathrm{O}: 4.47 \% ; \mathrm{Na}_{2} \mathrm{O}: 3.59$

$15 \% ; \mathrm{Fe}_{2} \mathrm{O}_{3}: 1.98 \%$; moreover it contains about $4 \%$ of bound water (structural water) and traces of 16 other compounds (e.g. $\mathrm{CaO}, \mathrm{SO}_{3}, \mathrm{MgO}, \mathrm{TiO}_{2}, \mathrm{FeO}, \mathrm{MnO}, \mathrm{P}_{2} \mathrm{O}_{5}$ ). Although pumice exhibited a non 17 negligible removal capacity for heavy metals (Moraci and Calabrò, 2010; Calabrò et al., 2011), it 18 was used here as an operational inert material with the virtual capacity of storing corrosion products 19 in its pores and retarding clogging (Moraci and Calabrò, 2010; Noubactep and Caré, 2010; 20 Noubactep et al. 2012a; Noubactep et al. 2012b). The material is characterized by uniform grain 21 size distribution. The mean grain size $\left(\mathrm{d}_{50}\right)$ is about $0.3 \mathrm{~mm}$ and the coefficient of uniformity (U) is 221.4 (see Supporting Information).

23 Metallic iron: the used $\mathrm{Fe}^{0}$ is of the type FERBLAST RI 850/3.5, distributed by Pometon S.p.A., 24 Mestre - Italy. The material contents mainly iron (> 99.74\%). Identified impurities included mainly $25 \mathrm{Mn}(0.26 \%), \mathrm{O}, \mathrm{S}$ and $\mathrm{C}$. The material is characterized by uniform grain size distribution. The 
1 mean grain size $\left(\mathrm{d}_{50}\right)$ is about $0.5 \mathrm{~mm}$ and the coefficient of uniformity (U) is 2 (see Supporting

2 Information).

3 The microstructure of used $\mathrm{Fe}^{0}$ and pumice was characterized using Mercury Intrusion Porosimetry

4 (MIP) measurements and by Scanning Electron Microscopy (SEM) observations (see Supporting 5 Information).

\section{$6 \quad 2.3 \quad$ Columns experiments}

7 The used solutions were obtained by dissolving copper nitrate, nickel nitrate and zinc nitrate in 8 distilled water. The molar concentration of the resulting solution was as follows: $0.27 \mathrm{M} \mathrm{Cu}, 0.29$

$9 \quad \mathrm{M} \mathrm{Ni}$ and $0.37 \mathrm{M} \mathrm{Zn}$. The corresponding mass concentrations are $17 \mathrm{mg} / \mathrm{L} \mathrm{Cu}, 17 \mathrm{mg} / \mathrm{L} \mathrm{Ni}$, and 23 $10 \mathrm{mg} / \mathrm{L} \mathrm{Zn}$.

11 No attempt was made to control the mass of dissolved oxygen (DO) present during the column 12 experiments. The main source of molecular oxygen is the air in the headspace of the PE bottles. It 13 can be assumed that the model solutions contained up to $8 \mathrm{mg} / \mathrm{L} \mathrm{DO}$. The role of dissolved oxygen 14 in accelerating the kinetics of aqueous iron corrosion is well-documented (e.g. Cohen, 1959; 15 Stratmann and Müller, 1994). Using an oxic solution is a tool to enable the characterization of 16 clogging under relevant conditions at reasonable experimental durations.

17 Simplified model solutions (no carbonates, bicarbonates and relevant cations) were used as this 18 work is a seminal one focused on the impact of molecular $\mathrm{O}_{2}$ on the clogging process of $\mathrm{Fe}^{0} \mathrm{PRBs}$ 19 as influenced by pumice addition in various proportions. Testing more complex solutions relevant 20 to simulate natural situation could be built on the results from these simplified systems.

21 Laboratory scale polymethyl methacrylate (Plexiglas) columns were operated in up-flow mode. The 22 influent solution was pumped upwards from a single PE bottle using a precision peristaltic pump 23 (Ismatec, ISM930). In all the tests the flow rate was maintained constant at a value of $0.5 \mathrm{~mL} / \mathrm{min}$. 24 Tygon tubes were used to connect inlet reservoir, pump, columns and outlet. Six plexiglas columns 25 (50 cm long, $5.0 \mathrm{~cm}$ inner diameter) were used in the experiments (Fig. 1). 
1 The ratio column diameter (D) to average material particle size (d) ensured the prevention of

2 channelling and wall effects. In fact, used D/d ratio (actually 100 to 165) is by far larger than the 3 threshold value of 50 (Badruzzaman and Westerhoff, 2005).

4 Six different systems were investigated (Systems A through F) (Tab. 1). System A was the 5 operational reference system containing only pumice $\left(0 \% \mathrm{Fe}^{0}\right)$ and system $\mathrm{F}$ was a pure iron 6 column $\left(100 \% \mathrm{Fe}^{0}\right)$. The volumetric proportion of $\mathrm{Fe}^{0}$ in the 4 other systems was $10,25,50$ and $775 \%$ following a procedure recently presented (Noubactep and Caré, 2011; Noubactep et al. 8 2012b). In systems $B$ to F, the mass of iron was fixed to $200 \mathrm{~g}$. This mass represented either $100 \%$ 9 of the reactive zone (rz) or the relevant volumetric proportion of rz (Fig. 1, Tab. 1). Tab. 1 10 summarizes the theoretical ( $\mathrm{rZ}_{\mathrm{theor}}$; i.e. the height of the column occupied by the reactive medium if $11 \mathrm{Fe}^{0}$ and pumice were used in series and not as a mixture) and measured ( $\mathrm{rz}$ eff i.e. the height of the 12 reactive zone in the column effectively measured) reactive zone for each individual systems.

13 The hydraulic conductivity was determined during the column tests, by either constant-head (k > $\left.1410^{-6} \mathrm{~m} / \mathrm{s}\right)$ or variable-head $\left(\mathrm{k}<10^{-6} \mathrm{~m} / \mathrm{s}\right)$ permeability methods (Head and Keeton, 2008), at given 15 times to assess the permeability of the systems. During hydraulic conductivity determinations, the 16 test was interrupted and a tank or a burette, filled with the same contaminated solution used during 17 the test, was connected to the column in order to carry out the appropriate procedure. At the end of 18 the permeability test the flow in the column was re-established with the operation mode illustrated 19 before. The duration of these procedures was very limited therefore the disturbance to the test was 20 fully acceptable. The column tests were performed at room temperature $\left(21 \pm 4{ }^{\circ} \mathrm{C}\right)$. Solution 21 specimens for analysis were collected from the columns outlet at periodic intervals and the 22 experiments where prolonged until contaminant breakthrough (system A) or a significant loss of the 23 hydraulic conductivity (systems C to F) was observed; only system B was voluntarily stopped after 2490 days. Tab. SI summarizes the experimental research program (Supporting Information). 
1 The aqueous concentrations of $\mathrm{Cu}, \mathrm{Ni}$ and $\mathrm{Zn}$ were determined by Atomic Absorption

2 Spectrophotometry (AAS - Shimadzu AA - 6701F) using conventional Standard Methods (APHA $32005)$.

\section{$4 \quad 2.4 \quad$ Expression of the experimental results}

5 In order to characterize the magnitude of tested systems for contaminant removal, the removal

6 efficiency (E) and the specific removal $\left(\mathrm{E}_{\mathrm{s}}\right)$ were calculated using Eq. 1 and Eq. 2 (Moraci and

7 Calabrò, 2010; Btatkeu et al., 2013).

8

9

11 contaminant, and $\mathrm{m}_{\mathrm{Fe}}$ the mass of $\mathrm{Fe}^{0}$ present in the column.

\section{$123 \quad$ Results and discussion}

\section{$13 \quad 3.1 \quad$ Contaminant removal}

14 The presentation is based on the concept that tested contaminants are removed in $\mathrm{Fe}^{0}$ columns (at $15 \mathrm{pH}>5$ ) by adsorption, co-precipitation and adsorptive size-exclusion (Noubactep, 2008; 2010; 16 2011). Given the importance of the $\mathrm{pH}$ value for this concept, the results of $\mathrm{pH}$ monitoring are 17 presented first.

\section{$18 \quad 3.1 .1 \quad \mathrm{pH}$ value}

19 Figure 2 summarizes the results of the evolution of the $\mathrm{pH}$ value in all investigated systems. It is 20 shown that in the reference system (100\% pumice), the initial $\mathrm{pH}(6.3)$ decreased to 5.8 and 21 remained constant for the entire column tests duration. The slight $\mathrm{pH}$ decrease could be attributed to 22 acidic sites at the pumice surface (Eq. 3). In all other systems, the $\mathrm{pH}$ value first increased to value $23>9.0$ and progressively decreased to values close to $6.0-7.0$. The observed $\mathrm{pH}$ increase is certainly 24 due to iron corrosion which consumes $\mathrm{H}^{+}$(Eq. 4).

$$
\mathrm{SiO}_{2(\mathrm{~s})}+2 \mathrm{H}_{2} \mathrm{O} \Rightarrow \mathrm{H}_{4} \mathrm{SiO}_{4}(\mathrm{aq})
$$


2 The subsequent progressive decrease of the $\mathrm{pH}$ value is consistent with lowered kinetics of iron

3 corrosion due to the formation of an oxide scale at the $\mathrm{Fe}^{0}$ surface (Cohen, 1959; Evans, 1969;

4 Aleksanyan et al., 2007; Nesic, 2007). The most important issue from Fig. 2 is that for all $\mathrm{Fe}^{0}$ -

5 containing systems, the effluent $\mathrm{pH}$ value is higher than 5.0. This suggests that contaminant

6 removal by adsorption, co-precipitation and adsorptive size-exclusion (Noubactep, 2011) could be

7 quantitative within these columns.

\section{$8 \quad 3.1 .2 \quad$ Iron release}

9 Figure 3 summarizes the results of the evolution of dissolved iron concentration in the effluent. It is

10 evident from Fig. 3a, that the highest iron release was observed in the system with the lowest $\mathrm{Fe}^{0}$ 11 ratio $\left(\mathrm{B}, 10 \% \mathrm{Fe}^{0}\right)$. The lowest $\mathrm{Fe}^{0}$ ratio corresponds to the highest amount of pumice (243 $\mathrm{g}-\mathrm{Tab}$.

12 1), acidifying the system after Eq. 3. The transport of iron corrosion products is certainly favoured 13 at low $\mathrm{pH}$ values and may be favoured by larger porosity (Nimmo, 2004; Woudberg and Du Plessis, 14 2008; Glover and Walker, 2009). In other words, in all other systems, even more iron could be 15 dissolved but it is retained within the system by (i) adsorption onto available iron oxides or onto 16 pumice, or (ii) precipitation as iron (hydr)oxides (Miyajima, 2012; Miyajima and Noubactep, 2013).

17 It is very important to notice that the extent of iron release depends primarily on the intrinsic 18 reactivity of used $\mathrm{Fe}^{0}$. Although data on iron release from column experiments are available in the 19 literature (e.g. Westerhoff and James, 2003) it is impossible to make a quantitative comparison. In 20 fact, a parameter (or an index) to characterize the intrinsic reactivity of $\mathrm{Fe}^{0}$ is still lacking 21 (Noubactep et al., 2009; Noubactep, 2012).

22 Fig. 3b shows that, apart from system B (10:90), in all other systems less than $1 \mathrm{mg} / \mathrm{L}$ iron was 23 released in the effluent solution. It is interesting to note that, for the remaining systems, the two 24 columns with the largest proportion of $\mathrm{Fe}^{0}$ (50 and $100 \%$ ) exhibited the highest iron release.

\subsubsection{Metal concentration}


1 Table 2 summarizes the results of the removal of $\mathrm{Cu}^{\mathrm{II}}, \mathrm{Ni}^{\mathrm{II}}$ and $\mathrm{Zn}^{\mathrm{II}}$ in terms of removal efficiency

$2 \mathrm{E}$, and of specific removal efficiency $\mathrm{E}_{\mathrm{s}}$ for all the 5 systems containing $\mathrm{Fe}^{0}$. While, reading this 3 table, it should be kept in mind that the experimental duration was variable as most of the 4 experiments were stopped because of significant permeability loss (see Tab. 1). Nevertheless, it can 5 be seen that 367 to $2881 \mathrm{mg}$ of individual contaminants flowed into the columns and were retained 6 with an efficiency $\mathrm{E}>90.0 \%$. Moreover, the specific efficiency $\left(\mathrm{E}_{\mathrm{s}}\right)$ varied from 1.7 to $13.6 \mathrm{mg}$ 7 contaminant per $\mathrm{g}$ of $\mathrm{Fe}^{0}$.

8 An important feature from Tab. 2 regards the suitability of $E_{\mathrm{s}}$ values (Eq. 2) for the characterization 9 of processes occurring in $\mathrm{Fe}^{0} / \mathrm{H}_{2} \mathrm{O}$ systems (Btatkeu et al., 2013; Miyajima and Noubactep, 2013). 10 Normalizing the extent of contaminant removal ( $\mathrm{m}_{\text {rev }}$ - Eq. 2 ) by the available amount of $\mathrm{Fe}^{0}$ (here $11200 \mathrm{~g}$ ) is only valid, if there is a clear linear relationship between iron corrosion and contaminant 12 removal. Such a relationship has not been demonstrated in the $\mathrm{Fe}^{0}$ remediation literature despite 13 repeated reports on reaction orders. Moreover, an adequate argumentation for adsorptive processes 14 has been simply transposed to systems, where adsorption is only one (and not necessarily the 15 dominant) removal path.

16 In pure adsorption systems (e.g. activated carbon, iron oxide, clay), the whole mass of adsorbing 17 material is present at the start of the removal process $\left(\mathrm{t}_{0}\right.$ or $\left.\mathrm{t}=0\right)$, its adsorption capacity can be 18 exhausted with the time. In a $\mathrm{Fe}^{0}$ system on the contrary, adsorbing species are generated in situ 19 after the start of the experiment $\left(t>t_{0}\right)$. Accordingly the extent of contaminant removal depends on 20 the kinetics of iron corrosion and the affinity of contaminants for corrosion products as far as pure 21 adsorption is concerned. Additionally, contaminants are also removed by co-precipitation and size22 exclusion. In other words, normalizing the extent of contaminant removal by the $\mathrm{Fe}^{0}$ amount 23 requires at least the knowledge of the intrinsic reactivity of used $\mathrm{Fe}^{0}$ and the impact of operational 24 parameters thereon. The most relevant operational parameter in the present work is the volumetric $25 \quad \mathrm{Fe}^{0}$ :pumice ratio. 
1 Figure 4 shows that the influence of the volumetric $\mathrm{Fe}^{0}$ :pumice ratio on the removal efficiency of

$2 \mathrm{Cu}^{2+}, \mathrm{Ni}^{2+}, \mathrm{Zn}^{2+}$ is very similar to the influence of the adsorbent amount on adsorption of $\mathrm{Mn}^{2+}$ by

3 clay minerals (Goldani et al., 2013). These authors reported on a decreasing trend of the adsorption

4 capacity $\left(\mathrm{q}_{\mathrm{e}}\right.$ value $/ \mathrm{mg} \mathrm{g}^{-1}$ ) for $\mathrm{Mn}^{2+}$ with increasing adsorbent amount (50 to $500 \mathrm{mg}$ ). This

5 observation was mainly rationalized by the fact that a large adsorbent amount reduces the

6 unsaturation of the adsorption sites. Correspondingly, the number of such sites per unit mass comes

7 down resulting in comparatively less adsorption at higher adsorbent amount. In the present work,

8 the $\mathrm{Fe}^{0}$ amount is constant (200 g), only its volumetric ratio in the mixture to pumice varies.

9 Moreover, a higher $\mathrm{Fe}^{0}$ ratio is coupled to a shorter reactive zone (e.g. $2.6 \mathrm{~cm}$ for $100 \% \mathrm{Fe}^{0}$ and

$1026.2 \mathrm{~cm}$ for $\left.10 \% \mathrm{Fe}^{0}\right)$. Thus, a higher $\mathrm{Fe}^{0}$ volumetric ratio may create particle aggregation

11 (cementation), decreasing the total number of adsorption sites, decreasing the porosity of the

12 reactive zone, and increasing the diffusion path to adsorption sites. Altogether, these factors

13 contribute to the decrease of the amount of contaminant adsorbed, assuming that the same amount

14 of adsorbent is generated in all systems. As summarized in Tab. 2, except system B (10\% $\left.\mathrm{Fe}^{0}\right)$,

15 metal removal was quantitative in all other systems.

16 Contaminant breakthrough was observed in other systems only short before the experiment was

17 stopped and was mainly attributed to transport through preferential flow paths (Miyajima and

18 Noubactep, 2013a and ref. cited therein). Even under such conditions the concentration of $\mathrm{Cu}$ and

$19 \mathrm{Zn}$ remained below $1 \mathrm{mg} / \mathrm{L}$ whereas the concentration of $\mathrm{Ni}$ exceeded $4 \mathrm{mg} / \mathrm{L}$ for system $\mathrm{F}(100 \%$

$\left.20 \mathrm{Fe}^{0}\right)$ and system $\mathrm{D}\left(50 \% \mathrm{Fe}^{0}\right)$ but not for system $\mathrm{E}\left(75 \% \mathrm{Fe}^{0}\right)$. This anomaly in the sequence D/E/F

21 confirms that the process responsible for metal breakthrough near system clogging is probably a

22 meta-stable one (preferential flow).

\section{$23 \quad 3.2 .4$ Mechanism of contaminant removal}

24 The experimental data previously described has shown that contaminants are quantitatively

25 removed in columns with volumetric $\mathrm{Fe}^{0}$ ratio higher than $10 \%$ until the system is almost clogged. 
1 In the system with $10 \% \mathrm{Fe}^{0}$, quantitative iron release is observed (Fig. 5). Quantitative iron release

2 coincided with minimal contaminant removal (or contaminant breakthrough) as discussed above.

3 This section further discusses the behaviour of system B (Fig. 5a).

4 The ionic radii of the investigated cations increase in the order $\mathrm{Ni}^{2+}<\mathrm{Cu}^{2+}<\mathrm{Zn}^{2+}$. The metallic

5 ions are removed by four different mechanisms (Herbert, 1996; Wang and Qin, 2007; Vodyanitskii,

6 2010): (i) co-precipitation with iron hydroxides, (ii) adsorption onto the (hydr)oxide surfaces, (iii)

7 isomorphic substitution for Fe in the iron oxide structure, or adsorptive size-exclusion. In multi-

8 element systems, the most common reported affinity sequence for iron oxides and soils is $\mathrm{Cu}>\mathrm{Zn}$

$9>\mathrm{Ni}$ (Moreira and Alleoni, 2010). This trend is confirmed by Fig. 5b.

10 Fig. 5a illustrates the fact that contaminants breakthrough occurs when increased iron release is

11 observed. For example, no significant breakthrough was observed in system $\mathrm{B}$ until t=30 days

12 although up to $8 \mathrm{mg} / \mathrm{L} \mathrm{Fe}$ was released into the outlet solution. For $\mathrm{t}>30$ days $\mathrm{Zn}$ and $\mathrm{Ni}$

13 breakthrough occurs and the breakthrough magnitude is in agreement with the affinity sequence for

14 iron oxides $(\mathrm{Cu}>\mathrm{Zn}>\mathrm{Ni})$. Accordingly, breakthrough is first observed for less bounded $\mathrm{Ni}$

15 followed by $\mathrm{Zn}$. As concerning $\mathrm{Cu}$ no breakthrough was observed through the end of the

16 experiment. At first glance, this observation could be attributed to $\mathrm{Cu}^{\mathrm{II}}$ cementation at the surface of

$17 \mathrm{Fe}^{0}$ in the column. In fact, $\mathrm{Cu}$ reduction to elemental $\mathrm{Cu}\left(\mathrm{Cu}^{0}\right)$, as mentioned above, is very

18 favourable and is used in many hydrometallurgical processes (Gros et al., 2011a; 2011b). However,

19 because $\mathrm{Cu}$ removal in this study occurred at $\mathrm{pH}>5$ (section 3.2.1), the $\mathrm{Fe}^{0}$ surface was necessarily

20 covered by iron (hydr)oxides (Aleksanyan et al., 2007; Nesic, 2007) and was not directly accessible

21 to $\mathrm{Cu}^{\mathrm{II}}\left(\mathrm{Ni}^{\mathrm{II}}\right.$ and $\left.\mathrm{Zn}^{\mathrm{II}}\right)$. More detailed discussion on the removal of metallic ions by $\mathrm{Fe}^{0}$ in multi-

22 elements system is given for instance by Cantrell et al.(1995), Qiu et al. (2000), Bartzas et al.

23 (2006), Komnitsas et al. (2006; 2007) and Scott et al. (2011).

24 It should be recalled that in a $\mathrm{Fe}^{0} / \mathrm{H}_{2} \mathrm{O}$ system, so-called structural $\mathrm{Fe}^{\mathrm{II}}$ (adsorbed $\mathrm{Fe}^{\mathrm{II}}$ ) is available

25 and is, in some circumstances, a more efficient reducing agent than $\mathrm{Fe}^{0}$ (White \& Peterson, 1996). 
1 Accordingly, $\mathrm{Cu}^{\mathrm{II}}$ might be quantitatively removed within the oxide scale on iron. Even if $\mathrm{Cu}^{\mathrm{II}}$ is

2 reduced at the surface of $\mathrm{Fe}^{0}$, it will be enmeshed within the matrix of iron oxides as corrosion

3 proceeds. In conclusion, aqueous $\mathrm{Cu}^{\mathrm{II}}$ is also permanently removed by the process of iron corrosion

4 (enmeshment or co-precipitation). It should be also remembered that the stronger affinity of $\mathrm{Cu}^{\mathrm{II}}$ for

5 iron oxides (adsorption) is sufficient to rationalize the absence of $\mathrm{Cu}$ breakthrough for 90 days (Fig.

$65 b)$.

\section{$7 \quad 3.3 \quad$ Hydraulic conductivity}

8 The results presented in Fig. 6 clearly demonstrate that granular $\mathrm{Fe}^{0} /$ pumice mixtures are more

9 sustainable in terms of long term permeability than the pure $\mathrm{Fe}^{0} \mathrm{PRB}$ for the decontamination of

10 used model solution. Fig. 6a shows that the pure pumice systems exhibited an initial porosity of

$1172.6 \%$ while the porosity of the pure $\mathrm{Fe}^{0}$ system was $49.6 \%$ (Tab. 1). Fig. 6 b shows that the $100 \%$

$12 \mathrm{Fe}^{0}$ system was clogged after 17 days; the $25 \% \mathrm{Fe}^{0}$ system after 37 days and the $10 \% \mathrm{Fe}^{0}$ system

13 was still highly permeable after 90 days. Even though the $10 \% \mathrm{Fe}^{0}$ system was not efficient at

14 removing $\mathrm{Ni}$ and $\mathrm{Zn}$, such systems could be used to generate dissolved Fe for other purposes

15 including: (i) in-situ generation of Fe for contaminant removal (Khan et al., 2000; Pokhrel and

16 Viraraghavan, 2009) and (ii) oxygen scavenger to sink the $\mathrm{O}_{2}$ concentrations in above-ground

17 devices (Mackenzie et al., 1999; Noubactep and Schöner, 2010; Noubactep et al., 2010).

18 A fundamental feature from Fig. 6a is that it combines contaminant removal (here $\mathrm{E}_{\mathrm{s}}$ value for $\mathrm{Zn}$ )

19 and initial porosity. The initial porosity decreases linearly with increasing $\mathrm{Fe}^{0}$ ratio. This behaviour

20 is rationalized by the fact that a compact material $\left(\mathrm{Fe}^{0}\right)$ is admixed to a porous one (pumice). The

21 initial pore volume will be progressively filled by in situ generated iron corrosion products (Caré et

22 al., 2013) which adsorb and co-precipitate metal ions. Reduced pore volume increases size-

23 exclusion efficiency while decreasing permeability. The challenge of designing hybrid $\mathrm{Fe}^{0} / \mathrm{material}$

24 systems is to find out the optimal system concealing sustained permeability and efficient 
1 contaminant removal. Fig. 6a confirms/shows unambiguously that such a system should contain as

2 less $\mathrm{Fe}^{0}$ (volumetric proportion) as possible (Caré et al., 2013; Miyajima and Noubactep, 2013).

3 Considering the factor of 65 times to account for the differential kinetics of $\mathrm{Fe}^{0}$ oxidation under

4 oxic $\left(8 \mathrm{mg} / \mathrm{L} \mathrm{O}_{2}\right)$ and anoxic $\left(0 \mathrm{mg} / \mathrm{L} \mathrm{O}_{2}\right)$ conditions (Cohen, 1959), it can be argued that the

5 shortest experimental duration (17 days) reported here could corresponds to about 1105 days under

6 anoxic conditions. These are more than 3 years necessary to observe clogging under the

7 experimental conditions of this work after 17 days. This result justifies the use of oxic conditions to

8 investigate target processes under laboratory conditions. By performing parallel experiments with

9 various amounts of molecular $\mathrm{O}_{2}$ (Vidic and Suidan, 1991) a better characterization of the impact of

10 the availability of molecular $\mathrm{O}_{2}$ is possible. This effort is even urgently needed as $\mathrm{Fe}^{0}$ beds have

11 been proposed for an array of applications varying from pure anoxic (groundwater remediation) to

12 oxic (household filter) systems.

13 Fig. 7 depicts the evolution of the experimental duration and the residual porosity (modelled, see

14 below) as a function of the initial porosity of the columns containing $\mathrm{Fe}^{0}$. The lowest porosity (49.6

$15 \%)$ corresponds to system $\mathrm{F}\left(100 \% \mathrm{Fe}^{0}\right)$ and the largest $(70.5 \%)$ to system $\mathrm{B}\left(10 \% \mathrm{Fe}^{0}\right)$. It is seen

16 that the experimental duration (system sustainability) increases almost linearly with decreasing $\mathrm{Fe}^{0}$

17 proportion from 100 to $25 \%$. From 25 to $10 \% \mathrm{Fe}^{0}$ an abrupt increase of the experimental duration

18 is observed. These results are qualitatively confirmed by the evolution of the residual porosity for

$19 \eta=6.4$ (Fig. 7a) where $\eta$ is the coefficient of volumetric expansion of rust specimens (Caré et al., 20 2008).

21 The residual porosity $\left(\Phi(\mathrm{t}) / \Phi_{0}\right)$ is defined as the ratio of the porosity at time $\mathrm{t} \Phi(\mathrm{t})$ to the initial

22 porosity $\Phi_{0}$ induced by the formation of rust leading to porosity loss according to:

$$
\frac{\Phi(\mathrm{t})}{\Phi_{0}}=1-\frac{\Delta \mathrm{V}}{\Phi_{0} \cdot \mathrm{V}}
$$

24 Where $\Delta \mathrm{V}=(\eta-1)^{*} \mathrm{~V}$ is the effective volumetric expansion of the initial volume $\mathrm{V}$ of $\mathrm{Fe}^{0}$. 
1 The residual porosity which, acting as an indicator of the hydraulic conductivity, is given for all

2 systems in Fig. 7. The observed time-dependant decrease of the hydraulic conductivity is attributed

3 to two different factors: (i) the decrease of the effective pore-size as concentric layers of iron oxides

4 are formed on $\mathrm{Fe}^{0}$, and (ii) the filling of pores by precipitated $\mathrm{Fe}$ species that escaped out of the

5 oxide scale. Permeability loss due to in-situ generated particles is retarded when larger particle sizes

6 are used. Accordingly, as the grain-size increases, the loss of hydraulic conductivity should follow

7 the inverse trend. In other words, the kinetics of the occupation of the voids depends on the grain-

8 size of used particles (effective pore-size).

9 Theoretically, for spherical grains of uniform size (monosized), the grain diameter will not impact

10 initial porosity but only the void diameter. However, the total porosity generally increases with

11 increasing sorting (grain size distribution), decreases with increasing sphericity and roundness of

12 particles, decreases with the increasing of relative density (closer packing) (Gibb et al., 1984). All

13 these aspects have to be considered to discuss literature results as well.

14 It appears from Fig. 7a that the residual porosity tends to zero $\left(\Phi(\mathrm{t}) / \Phi_{0}=0\right.$ or permeability loss) for

15 clogged systems ( $\% \mathrm{Fe}^{0} \geq 25$ - clogging precedes $\mathrm{Fe}^{0}$ depletion). $\mathrm{For} \mathrm{Fe}^{0}<25 \%, \Phi(\mathrm{t}) / \Phi_{0} \neq 0$ at $\mathrm{Fe}^{0}$

16 depletion in accordance with the evolution of the hydraulic conductivity and the test duration. At

17 first glance, this observation could be misinterpreted as the confirmation of the proposed model. But

18 under the experimental conditions, $\mathrm{Fe}^{0}$ was not completely depleted. Accordingly, this experimental

19 evidence rather suggests that the entrance zone of the column could have been rapidly clogged due

20 to elevated $\mathrm{O}_{2}$ levels (Mackenzie et al., 1999). The presence of $\mathrm{O}_{2}$ leads to iron (hydr)oxides with

21 higher expansion coefficient $(\eta)$ implying a more rapid decrease of the residual porosity (Fig. 7b).

22 Fig. $7 \mathrm{~b}$ depicts the modelled variation of the residual porosity for 3 different values of $\eta(2.08,3.03$

23 and 6.4). It is seen that under ideal conditions (uniform corrosion), the sustainability of a $\mathrm{Fe}^{0}$ filter

24 depends on the availability of $\mathrm{O}_{2}$. Accordingly the most sustainable systems is the one operating 25 under conditions where $\mathrm{Fe}_{3} \mathrm{O}_{4}(\eta=2.08)$ is the major iron corrosion product (anoxic conditions). 
1 These conditions could be obtained in a second column in series with a first one acting as $\mathrm{O}_{2}$

2 scavenger.

3 The fact that observed preservation of permeability with time is coupled with a decrease of

4 contaminant removal efficiency suggests that for any $\mathrm{Fe}^{0}$ /additive couple, an increase of filter

5 sustainability with decreasing $\mathrm{Fe}^{0}$ proportion down to a threshold value (here $25 \% \mathrm{Fe}^{0}$ ) would be 6 observed.

7 This study has traceably demonstrated that admixing non expansive material with $\mathrm{Fe}^{0}$ is a tool to increase permeable reactive barriers sustainability. In other words, an efficient but not sustainable

9 system $\left(100 \% \mathrm{Fe}^{0}\right)$ is transformed into an efficient and more sustainable one by admixing a certain

10 volumetric proportion of pumice (here $\geq 75 \%$ ). The admixing material (here pumice) should 11 necessarily be less expensive than $\mathrm{Fe}^{0}$; thus, cost savings could be regarded as a positive side effect 12 of increased performance.

\section{$13 \quad 3.4 \quad$ Significance for future works}

14 This study is a continuation of a broad-based work aiming at designing non-site-specific $\mathrm{Fe}^{0}$

15 filtration systems for water treatment and environmental remediation in its third step.

16 The first step consisted in identifying the common underlying mechanisms for contaminant removal 17 (Noubactep, 2007; 2008; 2010; 2011). Adsorption, co-precipitation and size-exclusion were

18 identified as fundamental paths for water treatment in $\mathrm{Fe}^{0}$ packed beds (Noubactep, 2011). This

19 result belittled the importance of chemical reduction in the process of contaminant removal in $20 \mathrm{Fe}^{0} / \mathrm{H}_{2} \mathrm{O}$ systems and clearly demonstrated that $\mathrm{Fe}^{0}$ is not a relevant reducing agent under 21 environmental conditions. The strong fact that $\mathrm{Fe}^{0}$ is the parent of all reducing species (e.g. $\mathrm{Fe}^{\mathrm{II}}$, $22 \mathrm{Fe}_{3} \mathrm{O}_{4}$, green rust, $\mathrm{H} / \mathrm{H}_{2}$ ) should never be misinterpreted as 'contaminant reduction coupled with 23 electrochemical iron corrosion' (Noubactep, 2013b).

24 The second step consisted in writing the dimensionless equation of a $\mathrm{Fe}^{0}$ packed beds (Noubactep and Caré, 2010; Noubactep et al., 2010; Noubactep and Caré, 2011; Noubactep et al., 2012a; 
1 Noubactep et al., 2012b; Caré et al., 2013). It is important to notice, that the equation is based on

2 the volumetric fraction of the packed beds available for 'storing' corrosion products (total porosity)

3 (Noubactep and Caré, 2011). This theoretical work has shown that the volumetric ratio of $\mathrm{Fe}^{0}$ in a

4 granular mixture should ideally not exceed $60 \%$. The basics for a systematic research for non-site-

5 specific $\mathrm{Fe}^{0}$ filtration systems were established. In particular each $\mathrm{Fe}^{0}$ material should be

6 characterized for its intrinsic reactivity; all used materials should be characterized for their form,

7 homogeneity and shape (Crane and Noubactep, 2012; Noubactep et al., 2012a; Caré et al., 2013).

8 The current third step consists in validation the equation of the column (Calabrò et al., 2011;

9 Biliardi et al., 2013a; Biliardi et al., 2013b). In this effort methylene blue (MB) was positively

10 tested as an operational tracer (Miyajima, 2012; Btatkeu et al., 2013; Miyajima and Noubactep,

11 2013). Experiments with $\mathrm{MB}$ confirmed theoretical predictions that a pure $\mathrm{Fe}^{0}$ bed is not

12 sustainable. Moreover, it could be shown that the optimal volumetric $\mathrm{Fe}^{0}$ ratio for sustainable filters

13 is lower $50 \%$. Given the large density difference between $\mathrm{Fe}^{0}\left(7.8 \mathrm{~g} \mathrm{~cm}^{3}\right)$ and commonly tested

14 additives (e.g. anthracite, gravel, pumice, sand) $\left(<3.0 \mathrm{~g} \mathrm{~cm}^{3}\right)$, this results clearly shows that the

15 commonly used 1:1 weight ratio is not optimal as well. Experiments with MB suggested that the

16 optimal $\mathrm{Fe}^{0}$ volumetric ratio in a dual $\mathrm{Fe}^{0} /$ sand system is comprised between 30 and $50 \%$.

17 The present work has systematically tested the $\mathrm{Fe}^{0}$ /pumice system for the first time using $\mathrm{Cu}, \mathrm{Ni}$ 18 and $\mathrm{Zn}$ as model contaminants. The results showed that the optimal $\mathrm{Fe}^{0}$ ratio for a sustainable filter 19 is $25 \%$. This result could be regarded as close to $30 \%$ as determined by Miyajima and Noubactep 20 (2013). However, under their experimental conditions, these authors could not experimentally 21 document permeability loss. Accordingly, the present work has provided the most reliable optimal $22 \mathrm{Fe}^{0}$ ratio for sustainable $\mathrm{Fe}^{0}$ filtration systems. In other words, this work provide the following rule 23 of thumb for further research (including pilot plant studies): "mix one volume of $\mathrm{Fe}^{0}$ and 3 volumes 24 of the additive(s)". The universal validity of this rule of thumb relies on the evidence that it is based 25 on a dimensionless equation. Thus, if a filter has to contain $1 \mathrm{~kg} \mathrm{Fe}^{0}$, the volume occupied by this 
$1 \quad \mathrm{Fe}^{0}$ mass is used as unit and three units volume of the additives of comparable size (and shape) are

2 to be added and homogenized.

\section{$3 \quad$ 4. Concluding remarks}

4 Environmental remediation and water treatment using metallic iron $\left(\mathrm{Fe}^{0}\right)$ in packed beds is an 5 established technology. Despite two decades of active research, this technology is still mostly

6 regarded as an innovative one or has been simply declared a developed one. However, a developed

7 technology is a technology that has established the scientific basis of the involved processes. This

8 work has clearly confirmed theoretical predictions that: (i) pure $\mathrm{Fe}^{0}$ beds are not sustainable as a

9 rule, (ii) a bed made up of $25 \% \mathrm{Fe}^{0}$ ( $\left.\mathrm{vol} / \mathrm{vol}\right)$ and $75 \%$ pumice is probably the most efficient

10 system concealing sustained permeability and increased efficiency for contaminant removal, (iii)

11 the specificity of contaminant removal in $\mathrm{Fe}^{0}$ filters fundamentally depends on the adsorptive 12 affinity to iron oxides (and not on the redox affinity).

13 The knowledge that the most sustainable filter is made up of more than $70 \%$ (vol/vol) of pumice

14 corroborates the view that sustainable $\mathrm{Fe}^{0}$ /aggregate filters are $\mathrm{Fe}^{0}$-amended aggregate filters (e.g.

$15 \mathrm{Fe}^{0}$-amended pumice filter or $\mathrm{Fe}^{0}$-amended sand filter). Most common natural aggregates are 16 anthracite, sand, gravel, pumice or crushed rock. However, manufactured aggregates (e.g. blast 17 furnace slag) can also be used as well. Basically there is an infinite number of $\mathrm{Fe}^{0}$-amended filters 18 as relevant aggregates may include activated carbon and biomaterial (e.g. wood and coconut shell).

$19 \mathrm{~A} \mathrm{Fe}^{0}$-amended filter can be regarded as a size-exclusion system in which size exclusion is 20 improved by in situ generated iron corrosion products. This is a typical case of self-filtration. The 21 challenge for future works is the proper design of these filters.

22 Further research at laboratory scale is needed to develop methodologies for the $\mathrm{Fe}^{0}$ filter design.

23 This effort should be accompanied by numerical modelling. Pilot scale installations are needed 24 afterwards to fine tune determine the practicality of several aspects optimised at lab scale.

\section{Acknowledgements}


1 The authors are grateful to Dott Giuseppe Panzera for its essential assistance during this research

2 activity and to the director and officials of the environmental protection sector of the province of

3 Reggio Calabria for authorisation to use their atomic absorption spectrophotometer. SEM

4 observations were performed at laboratory LMT Cachan, ENS de Cachan / CNRS / Université

5 Pierre et Marie Curie (Paris 6), France. The manuscript was improved by the insightful comments

6 of anonymous reviewers from Journal of Environmental Management.

\section{References}

Aleksanyan A.Y., Podobaev A.N., Reformatskaya I.I., 2007. Steady-state anodic dissolution of iron in neutral and close-to-neutral media. Protection of Metals 43, 66-69.

APHA, AWWA, WEF, 2005. Standard Methods for the examination of water and wastewater, 21st ed. American Public Health Association, Washington D.C. (USA).

Badruzzaman M., Westerhoff P., 2005. The application of rapid small-scale column tests in ironbased packed bed arsenic treatment systems, ACS Symposium Series, 915 (Advances in Arsenic Research): 268-283.

Bartzas G., Komnitsas K., 2010. Solid phase studies and geochemical modelling of low-cost permeable reactive barriers. J. Hazard. Mater. 183, 301-308.

Bartzas G., Komnitsas K., Paspaliaris I., 2006. Laboratory evaluation of $\mathrm{Fe}^{0}$ barriers to treat acidic leachates. Miner. Eng. 19, 505-514.

Bilardi S., Calabrò P.S., Caré S., Moraci N., Noubactep C., 2013a. Effect of pumice and sand on the sustainability of granular iron beds for the removal of $\mathrm{Cu}^{\mathrm{II}}, \mathrm{Ni}^{\mathrm{II}}$, and $\mathrm{Zn}^{\mathrm{II}}$. Clean - Soil, Air, Water, doi: 10.1002/clen.201100472.

Bilardi S., Amos R.T., Blowes D.W., Calabrò P.S., Moraci N., 2013b. Reactive Transport Modeling of ZVI Column Experiments for Nickel Remediation. Ground Water Monit. Remed., doi: 10.1111/j.1745-6592.2012.01417.x. 
1 Btatkeu K. B.D., Miyajima K., Noubactep C., Caré S., 2013. Testing the suitability of metallic iron for environmental remediation: Discoloration of methylene blue in column studies. Chem. Eng. J. 215-216, 959-968.

Calabrò P.S., Moraci N., Suraci P., 2011. Estimate of the optimum weight ratio in zero-valent iron/pumice granular mixtures used in permeable reactive barriers for the remediation of nickel contaminated groundwater. J. Hazard. Mater. 207-208, 111-116.

Cantrell K.J., Kaplan D.I., Wietsma T.W., 1995. Zero-valent iron for the in situ remediation of selected metals in groundwater. J. Hazard. Mater. 42, 201-212.

Caré S., Crane R., Calabro P.S., Ghauch A., Temgoua E., Noubactep C., 2012. Modelling the permeability loss of metallic iron water filtration systems. Clean - Soil, Air, Water, doi: 10.1002/clen.201200167.

Caré S., Nguyen Q.T., L'Hostis V., Berthaud Y., 2008. Mechanical properties of the rust layer induced by impressed current method in reinforced mortar. Cement Concrete Res. 38, 10791091.

Cohen M., 1959. The formation and properties of passive films on iron. Can. J. Chem. 37, 286-291.

Comba S., Di Molfetta A., Sethi R., 2011. A Comparison between field applications of nano-, micro-, and millimetric zero-valent iron for the remediation of contaminated aquifers. Water Air Soil Pollut. 215, 595-607.

Courcelles B., Modaressi-Farahmand-Razavi A., Gouvenot A., Esnault-Filet A., 2011. Influence of precipitates on hydraulic performance of permeable reactive barrier filters. Int. J. Geomech. $11,142-151$

Evans U.R., 1969. Mechanism of rusting. Corros. Sci. 9, 813-821.

Ghauch A., Abou Assi H., Baydoun H., Tuqan A.M., Bejjani A., 2011. Fe ${ }^{0}$-based trimetallic systems for the removal of aqueous diclofenac: Mechanism and kinetics. Chem. Eng. J. 172, 1033-1044. 
1 Gheju M., 2011. Hexavalent chromium reduction with zero-valent iron (ZVI) in aquatic systems. Water Air Soil Pollut. 222, 103-148.

Gheju M., Balcu I., 2011. Removal of chromium from Cr(VI) polluted wastewaters by reduction with scrap iron and subsequent precipitation of resulted cations. J. Hazard. Mater. 196, 131138.

Gibb J.P., Barcelona M.J., Ritchey J.D., LeFaivre M.H., 1984. Effective porosity of geologic materials: first annual report. Champaign, Ill; Illinois State Water Survey. SWS contract report 351.

Glover P.W.J., Walker E., 2009. Grain-size to effective pore-size transformation derived from electrokinetic theory. Geophysics 74, E17-E29.

Goldani E., Moro C.C., Maia S.M., 2013. A study employing differents clays for Fe and Mn removal in the treatment of acid mine drainage. Water Air Soil Pollut. 224, doi : $10.1007 / \mathrm{s} 11270-012-1401-4$

Gros F., Baup S., Aurousseau M., 2011. Copper cementation on zinc and iron mixtures: Part 2: Fluidized bed configuration. Hydrometallurgy 106, 119-126.

Gros F., Baup S., Aurousseau M., 2011. Copper cementation on zinc and iron mixtures: Part 1: Results on rotating disc electrode. Hydrometallurgy 106, 127-133.

Haarhoff J., Vessal A., 2010. A falling-head procedure for the measurement of filter media sphericity. Water SA $36,97-104$.

Head K.H., Keeton G.P., 2008. Permeability, shear strength \& compressibility tests, In: Manual of Soil Laboratory Testing, vol. 2. Whittles Publishing: United Kingdom.

Henderson A.D., Demond A.H., 2011. Impact of solids formation and gas production on the permeability of ZVI PRBs. J. Environ. Eng. 137, 689-696.

Herbert R.B., 1996. Metal retention by iron oxide precipitation from acidic ground water in Dalarna, Sweden. Appl. Geochem. 11, 229-235. 
1 ITRC (Interstate Technology \& Regulatory Council). 2011. Permeable reactive barrier: Technology update. PRB-5. Washington, D.C.: Interstate Technology \& Regulatory Council, PRB: Technology Update Team. www.itrcweb.org (access: 12.12.2012).

Jeen S.-W., Amos R.T., Blowes D.W., 2012. Modeling gas formation and mineral precipitation in a granular iron column. Environ. Sci. Technol. 46, 6742-6749.

Jiao Y., Qiu C., Huang L., Wu K., Ma H., Chen S., Ma L., Wu L., 2009. Reductive dechlorination of carbon tetrachloride by zero-valent iron and related iron corrosion. Appl. Catal. B: Environ. $91,434-440$.

Khan A.H., Rasul S.B., Munir A.K.M., Habibuddowla M., Alauddin M., Newaz S.S., Hussam A., 2000. Appraisal of a simple arsenic removal method for groundwater of Bangladesh. J. Environ. Sci. Health A 35, 1021-1041.

Knowles P., Dotro G., Nivala J., García J., 2011. Clogging in subsurface-flow treatment wetlands: Occurrence and contributing factors. Ecol. Eng. 37, 99-112.

Komnitsas K., Bartzas G., Fytas K., Paspaliaris I., 2007. Long-term efficiency and kinetic evaluation of ZVI barriers during clean-up of copper containing solutions. Miner. Eng. 20, $1200-1209$.

Komnitsas K., Bartzas G., Paspaliaris I., 2006. Inorganic contaminant fate assessment in zero-valent iron treatment walls. Environ. Forensics 7, 207-217.

Kubare M., Haarhoff J., 2010. Rational design of domestic biosand filters. J. Water Supply: Res. Technol. - AQUA 59 (1), 1-15.

Lavine B.K., Auslander G., Ritter J., 2001. Polarographic studies of zero valent iron as a reductant for remediation of nitroaromatics in the environment. Microchem. J. 70, 69-83.

Li L., Benson C.H., Lawson E.M., 2006. Modeling porosity reductions caused by mineral fouling in continuous-wall permeable reactive barriers. J. Contam. Hydrol. 83, 89-121. 
1 Li L., Benson C.H., 2010. Evaluation of five strategies to limit the impact of fouling in permeable reactive barriers. J. Hazard. Mater. 181, 170-180.

3 Liu H., Wang Q., Wang C., Li X.-z., 2013. Electron efficiency of zero-valent iron for groundwater remediation and wastewater treatment. Chem. Eng. J. 215-216, 90-95.

Mackenzie P.D., Horney D.P., Sivavec T.M., 1999. Mineral precipitation and porosity losses in granular iron columns. J. Hazard. Mater. 68, 1-17.

Miyajima K., 2012. Optimizing the design of metallic iron filters for water treatment. Freiberg Online Geoscience 32, 60 pp.

Miyajima K., Noubactep C., 2012. Impact of $\mathrm{Fe}^{0}$ amendment on methylene blue discoloration by sand columns. Chem. Eng. J. 217, 310-319.

Moraci N., Calabrò P.S., 2010. Heavy metals removal and hydraulic performance in zero-valent iron/pumice permeable reactive barriers. J. Environ. Manage. 91, 2336-2341.

Moreira C.S., Alleoni L.R.F., 2010. Adsorption of $\mathrm{Cd}, \mathrm{Cu}, \mathrm{Ni}$ and $\mathrm{Zn}$ in tropical soils under competitive and non-competitive systems. Sci. Agric. 67, 301-307.

Nesic S., 2007. Key issues related to modelling of internal corrosion of oil and gas pipelines - A review. Corros. Sci. 49, 4308-4338.

Nimmo JR. Porosity and pore size distribution. in Hillel D, editor. Encyclopedia of Soils in the Environment: London, Elsevier; 2004; 3:295-303.

Noubactep C., 2007. Processes of contaminant removal in " $\mathrm{Fe}^{0}-\mathrm{H}_{2} \mathrm{O}$ " systems revisited. The importance of co-precipitation. Open Environ. J. 1, 9-13.

Noubactep C., 2008. A critical review on the mechanism of contaminant removal in $\mathrm{Fe}^{0}-\mathrm{H}_{2} \mathrm{O}$ systems. Environ. Technol. 29, 909-920.

Noubactep C., Licha T., Scott T.B., Fall M., Sauter M., 2009. Exploring the influence of operational parameters on the reactivity of elemental iron materials. J. Hazard. Mater. 172, 943-951.

Noubactep C., 2010. The fundamental mechanism of aqueous contaminant removal by metallic iron. Water SA 36, 663-670. 
1 Noubactep C., Caré S., 2010. Enhancing sustainability of household water filters by mixing metallic iron with porous materials. Chem. Eng. J. 162. 635-642.

3 Noubactep C., Caré S., Togue-Kamga F., Schöner A., Woafo P., 2010. Extending service life of household water filters by mixing metallic iron with sand. Clean - Soil Air Water 38, 9515 959.

Noubactep C., Schöner A., 2010. Metallic iron: dawn of a new era of drinking water treatment research? Fresen. Environ. Bull. 19, 1661-1668.

Noubactep C., 2011. Aqueous contaminant removal by metallic iron: Is the paradigm shifting? Water SA 37, 419-426.

Noubactep C., Caré S., 2011. Designing laboratory metallic iron columns for better result comparability. J. Hazard. Mater. 189, 809-813.

Noubactep C., 2012. Characterizing the reactivity of metallic iron in $\mathrm{Fe}^{0} / \mathrm{As}-\mathrm{rock} / \mathrm{H}_{2} \mathrm{O}$ systems by long-term column experiments. Water SA. 38, 511-517.

Noubactep C., Caré S., Crane R.A., 2012a. Nanoscale metallic iron for environmental remediation: prospects and limitations. Water Air Soil Pollut. 223, 1363-1382.

Noubactep C., Temgoua E., Rahman M.A., 2012b. Designing iron-amended biosand filters for decentralized safe drinking water provision. Clean: Soil, Air, Water 40, 798-807.

Noubactep C., 2013a. On the suitability of admixing sand to metallic iron for water treatment. Int. J. Environ. Pollut. Solutions 1, 22-36.

Noubactep C., 2013b. Relevant reducing agents in remediation $\mathrm{Fe}^{0} / \mathrm{H}_{2} \mathrm{O}$ systems. Clean: Soil, Air, Water, doi:10.1002/clen.201200406.

O'Hannesin S.F., Gillham R.W., 1998. Long-term performance of an in situ "iron wall" for remediation of VOCs. Ground Water 36, 164-170.

Pilling N. B., Bedworth R.E., 1923. The oxidation of metals at high temperatures. J. Inst. Met. 29, $529-591$. 
1 Pokhrel D., Viraraghavan T., 2009. Biological filtration for removal of arsenic from drinking water. J. Environ. Manage. 90, 1956-1961.

Qiu S.R., Lai H.-F., Roberson M.J., Hunt M.L., Amrhein C., Giancarlo L.C., Flynn G.W., Yarmoff. 2000. Removal of contaminants from aqueous solution by reaction with iron surfaces. Langmuir 16, 2230-2236.

Ruhl A.S., Ünal N., Jekel M., 2012. Evaluation of two-component $\mathrm{Fe}(0)$ fixed bed filters with porous materials for reductive dechlorination. Chem. Eng. J. 209, 401-406.

Scott T.B., Popescu I.C., Crane R.A., Noubactep C., 2011. Nano-scale metallic iron for the treatment of solutions containing multiple inorganic contaminants. J. Hazard. Mater. 186, 280-287.

Smith M.R., Collis L., Fookes P.G., Lay J., Sims I., Smith M.R., West G., 2001. Aggregates for use in filter media. Geological Society, London, Engineering Geology Special Publications 17, 291-298.

Stratmann M., Müller J., 1994. The mechanism of the oxygen reduction on rust-covered metal substrates. Corros. Sci. 36, 327-359.

Vidic R.D., Suidan M.T., 1991. Role of dissolved oxygen on the adsorptive capacity of activated carbon for synthetic and natural organic matter. Environ. Sci. Technol. 25, 1612-1618.

Vodyanitskii Y.N., 2010. The role of iron in the fixation of heavy metals and metalloids in soils: a review of publications. Eurasian Soil Sci. 43, $519-532$.

Wang X.S., Qin Y., 2007. Relationships between heavy metals and iron oxides, fulvic acids, particle size fractions in urban roadside soils. Environ. Geol. 52, 63-69.

Westerhoff P., James J., 2003. Nitrate removal in zero-valent iron packed columns. Water Res. 37, $1818-1830$.

White A.F., Peterson M.L., 1996. Reduction of aqueous transition metal species on the surfaces of Fe(II)-containing oxides. Geochim. Cosmochim. Acta 60, 3799-3814. 
1 Woudberg S., Du Plessis J.P., 2008. Predicting the permeability of very low porosity sandstones. Transp. Porous Med. 73, 39-55.

3 You Y., Han J., Chiu P.C., Jin Y., 2005. Removal and inactivation of waterborne viruses using 4 zerovalent iron. Environ. Sci. Technol. 39, 9263-9269.

5 Zhang Y., Gillham R.W., 2005. Effects of gas generation and precipitates on performance of $\mathrm{Fe}^{0}$ 6 PRBs. Ground Water 43, 113-121.

7

8 
1 Table 1: Main characteristics of the studied columns. "Volume" is the apparent volume of granular

2 medium. " $r \mathrm{Z}_{\text {theor" }}$ is sum of the volumes occupied by the two media separately. "r $\mathrm{Z}_{\mathrm{eff}}$ " is the 3 measured reactive zone. The estimated porosity and the duration of the experiment are also given.

4

5

\begin{tabular}{|c|cc|cc|ccc|c|}
\hline System & \multicolumn{2}{|c|}{ Volume } & \multicolumn{2}{|c|}{ Mass } & \multicolumn{4}{c|}{ Column } \\
\hline & Fe $^{\mathbf{0}}$ & Pumice & Fe $^{\mathbf{0}}$ & Pumice & rz $_{\text {theor }}$ & rZ $_{\text {eff. }}$ & Porosity* & Duration \\
& $(\%)$ & $(\%)$ & $(\mathrm{g})$ & $(\mathrm{g})$ & $(\mathrm{cm})$ & $(\mathrm{cm})$ & $(\%)$ & $(\mathrm{day})$ \\
\hline $\mathbf{A}$ & 0 & 100 & 0.0 & 269.7 & 29.69 & 30.0 & 72.6 & 45 \\
$\mathbf{B}$ & 10 & 90 & 200.0 & 242.7 & 26.72 & 26.2 & 70.5 & 90 \\
$\mathbf{C}$ & 25 & 75 & 200.0 & 80.9 & 10.48 & 9.8 & 64.9 & $36^{* *}$ \\
$\mathbf{D}$ & 50 & 50 & 200.0 & 27.0 & 5.24 & 5.0 & 59.5 & $28^{* *}$ \\
E & 75 & 25 & 200.0 & 9.0 & 3.49 & 3.4 & 54.8 & $22^{* *}$ \\
F & 100 & 0 & 200.0 & 0.0 & 2.62 & 2.6 & 49.6 & $17^{* *}$ \\
\hline
\end{tabular}

$6 *$ in this values the internal porosity of the pumice is also included

$7 \quad * *$ stopped because of excessive permeability loss

8

9 
1 Table 2: Magnitude of contaminant removal in investigated systems. $\mathrm{m}_{\mathrm{in}}$ is the mass of contaminant

2 flowed into the column, $\mathrm{E}$ is the removal efficiency and $\mathrm{E}_{\mathrm{s}}$ the specific removal.

\begin{tabular}{|c|c|c|c|c|c|c|c|c|c|}
\hline \multirow[t]{3}{*}{ System } & \multicolumn{3}{|c|}{$\mathbf{m}_{\text {in }}$} & \multicolumn{3}{|c|}{$\mathbf{E}$} & \multicolumn{3}{|c|}{ Es } \\
\hline & $\mathrm{Ni}$ & $\mathrm{Cu}$ & $\mathrm{Zn}$ & $\mathrm{Ni}$ & $\mathrm{Cu}$ & $\mathrm{Zn}$ & $\mathrm{Ni}$ & $\mathrm{Cu}$ & $\mathrm{Zn}$ \\
\hline & \multicolumn{3}{|c|}{ (mg) } & \multicolumn{3}{|c|}{$(\%)$} & \multicolumn{3}{|c|}{$(\mathrm{mg} / \mathrm{g})$} \\
\hline B & 2130 & 2130 & 2881 & 90.1 & 99.8 & 94.2 & 9.58 & 10.6 & 13.6 \\
\hline C & 881.3 & 881.3 & 1192 & 98.7 & 99.9 & 99.9 & 4.53 & 4.40 & 5.96 \\
\hline D & 612 & 612 & 828 & 93.3 & 99.9 & 99.6 & 2.86 & 3.06 & 4.12 \\
\hline $\mathbf{E}$ & 514.1 & 514.1 & 695.5 & 97.9 & 99.9 & 99.9 & 2.52 & 2.57 & 3.47 \\
\hline $\mathbf{F}$ & 367.2 & 367.2 & 496.8 & 94.7 & 99.9 & 99.8 & 1.74 & 1.83 & 2.48 \\
\hline
\end{tabular}

3 


\section{$1 \quad$ Figure 1}

2

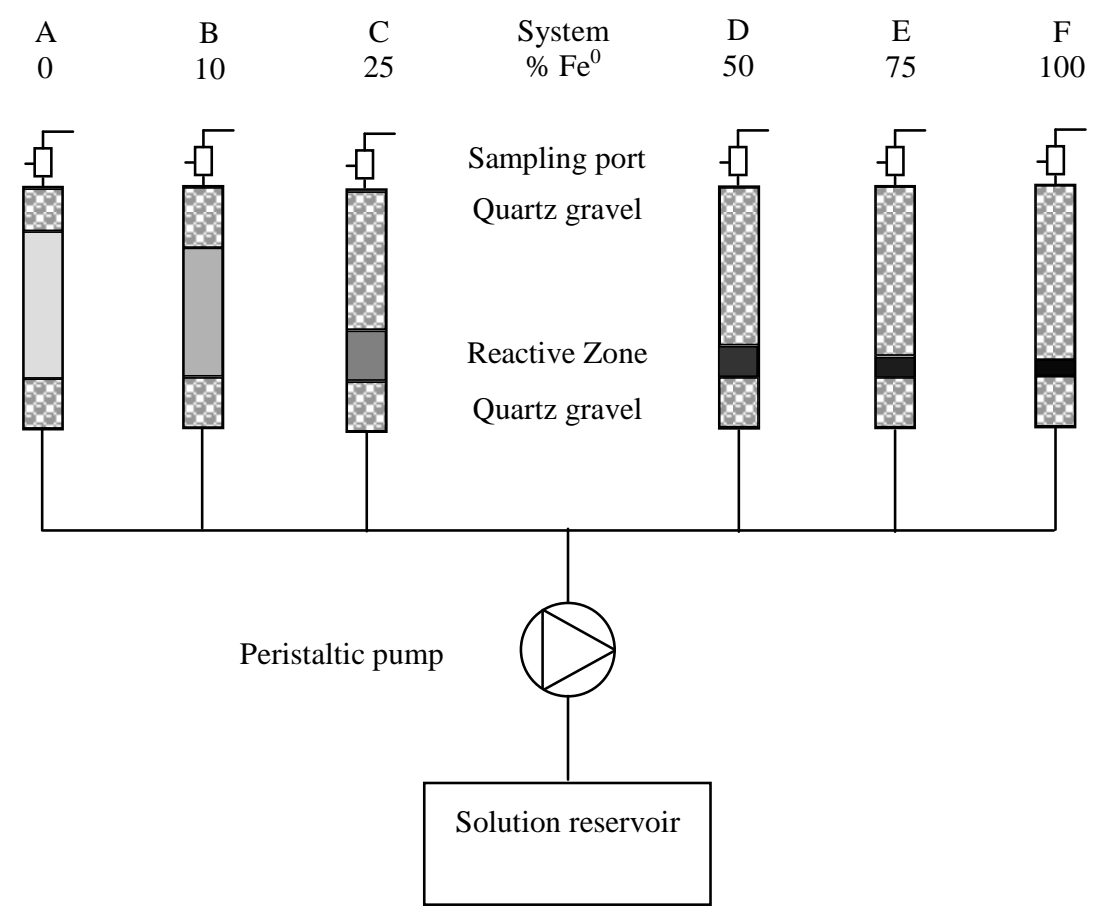

4 
$1 \quad$ Figure 2

2

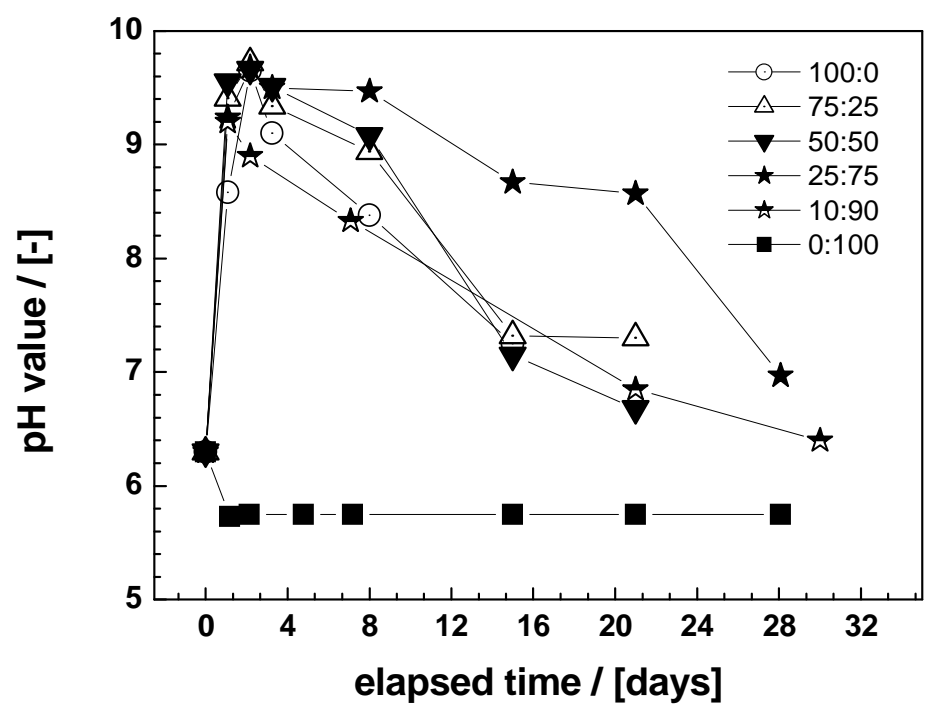

3

4 
$1 \quad$ Figure 3

2

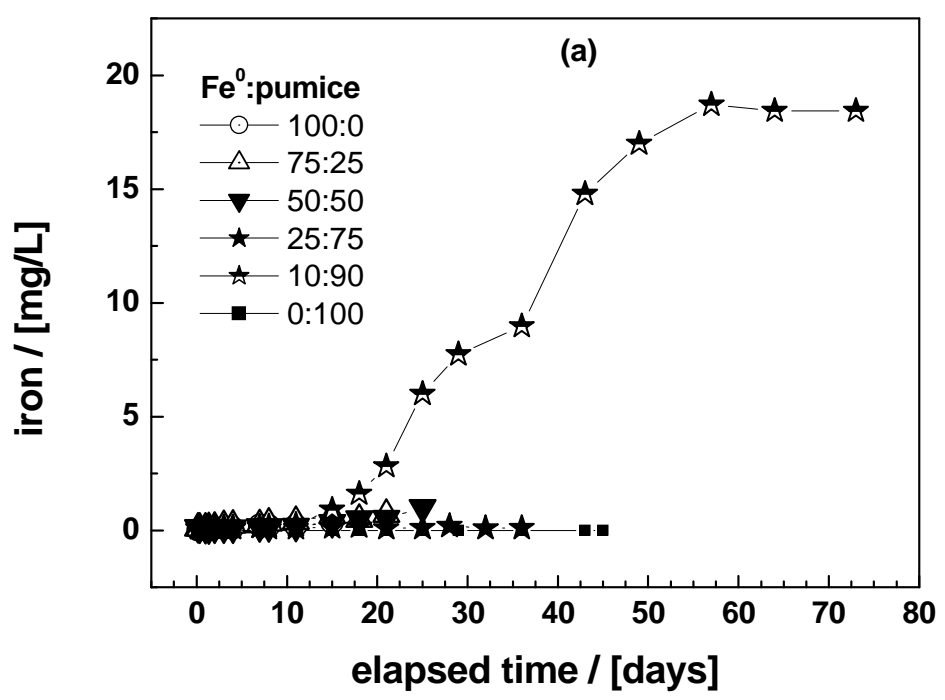

3

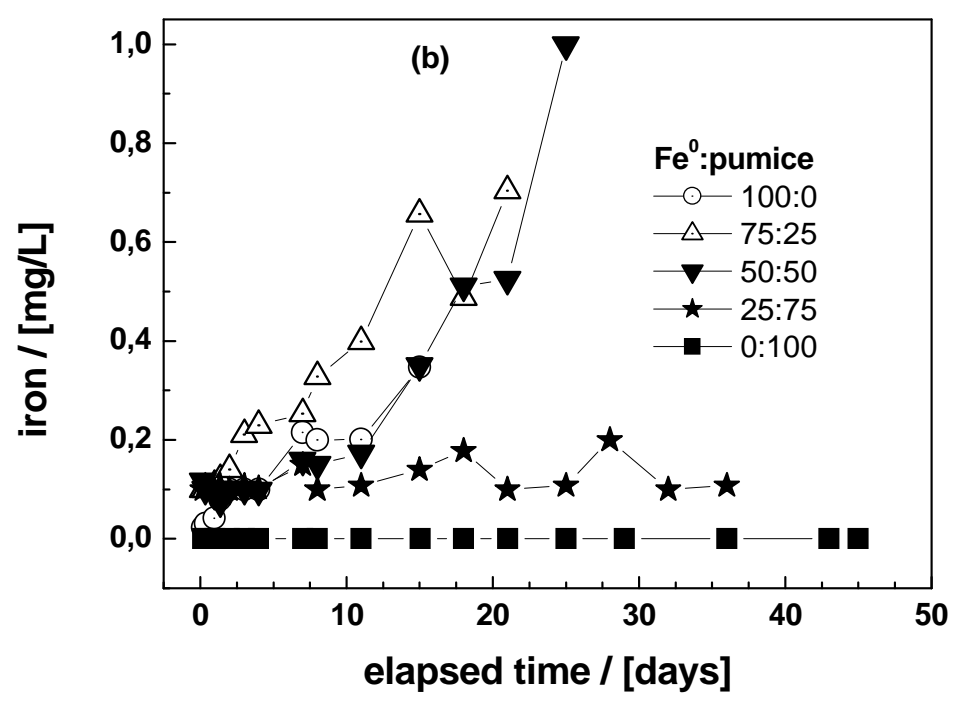

5

6 
$1 \quad$ Figure 4

2

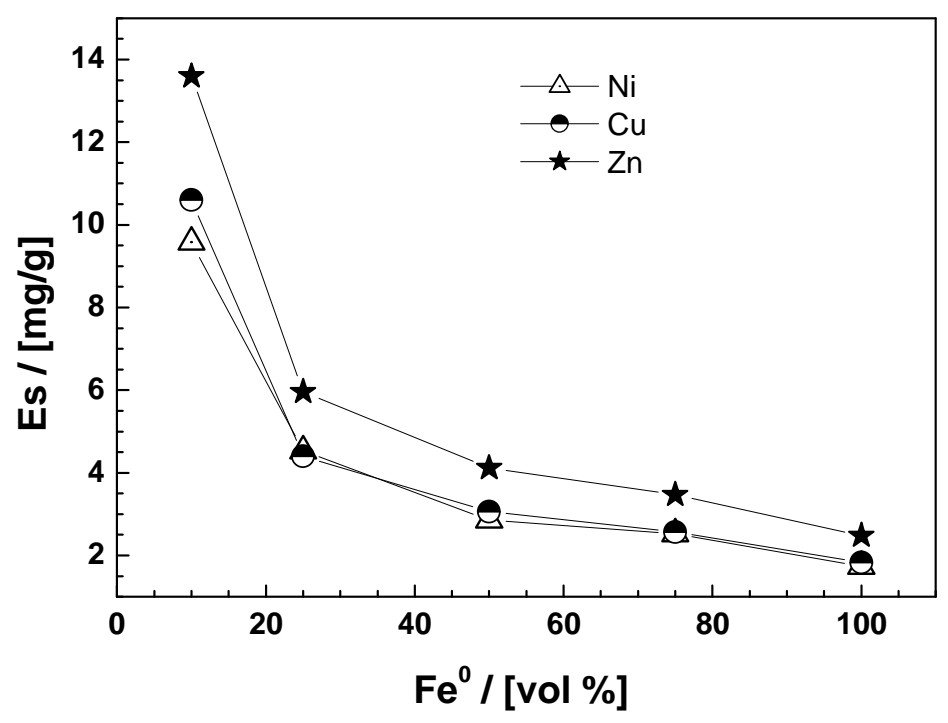

3

4

5 
$1 \quad$ Figure 5

2

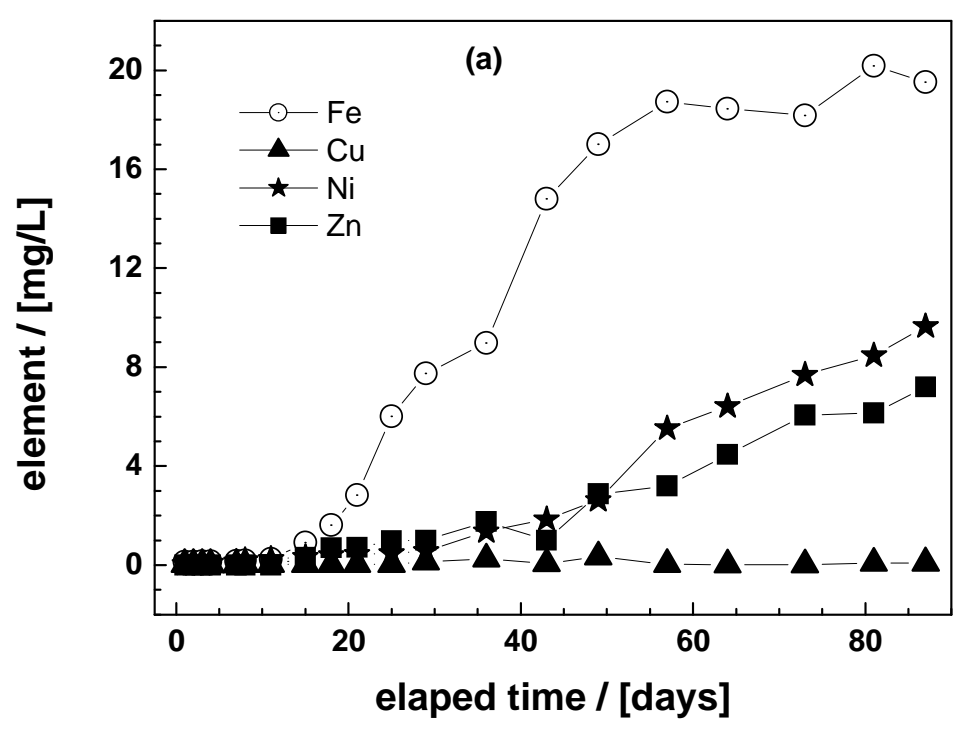

3

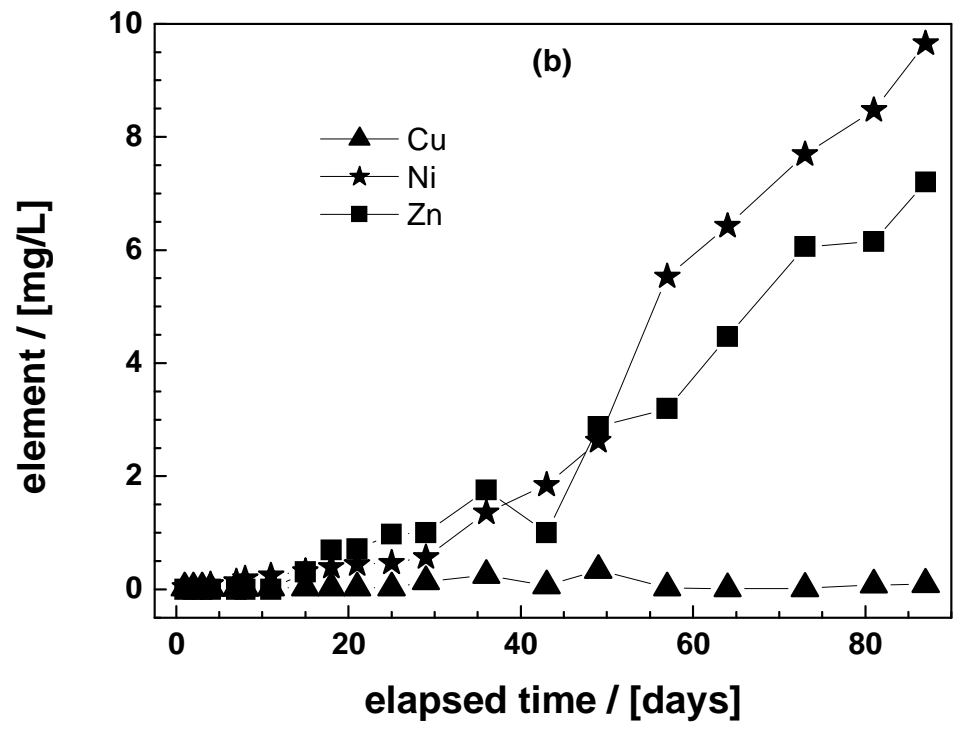

4

5

6

7 


\section{$1 \quad$ Figure 6}

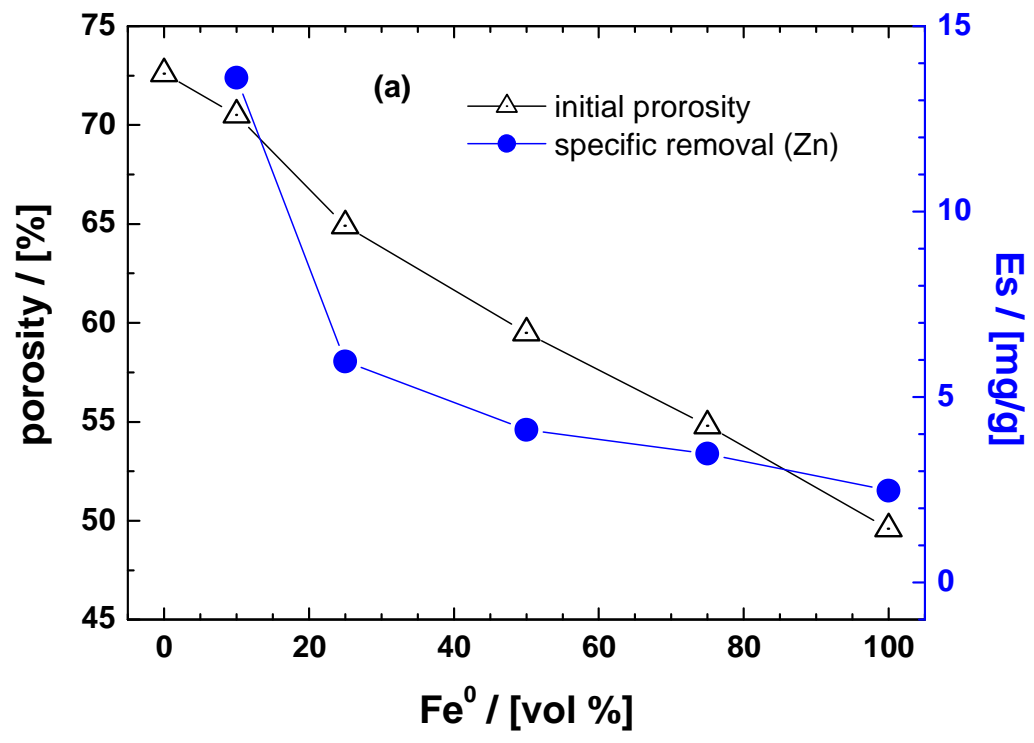

3

4

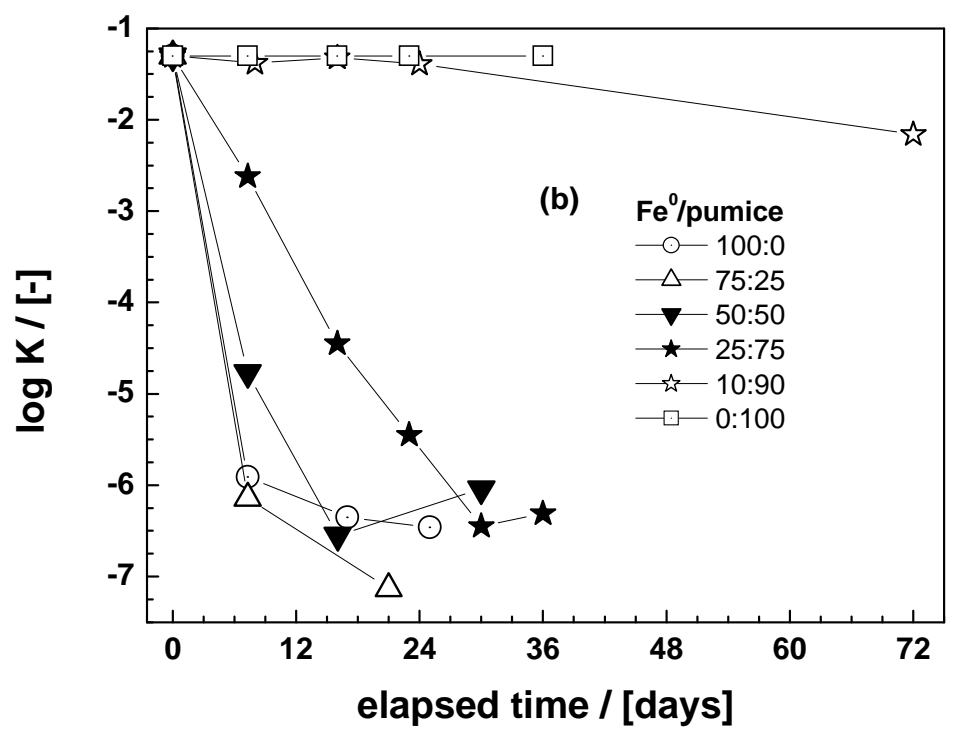

5

6 
$1 \quad$ Figure 7

2

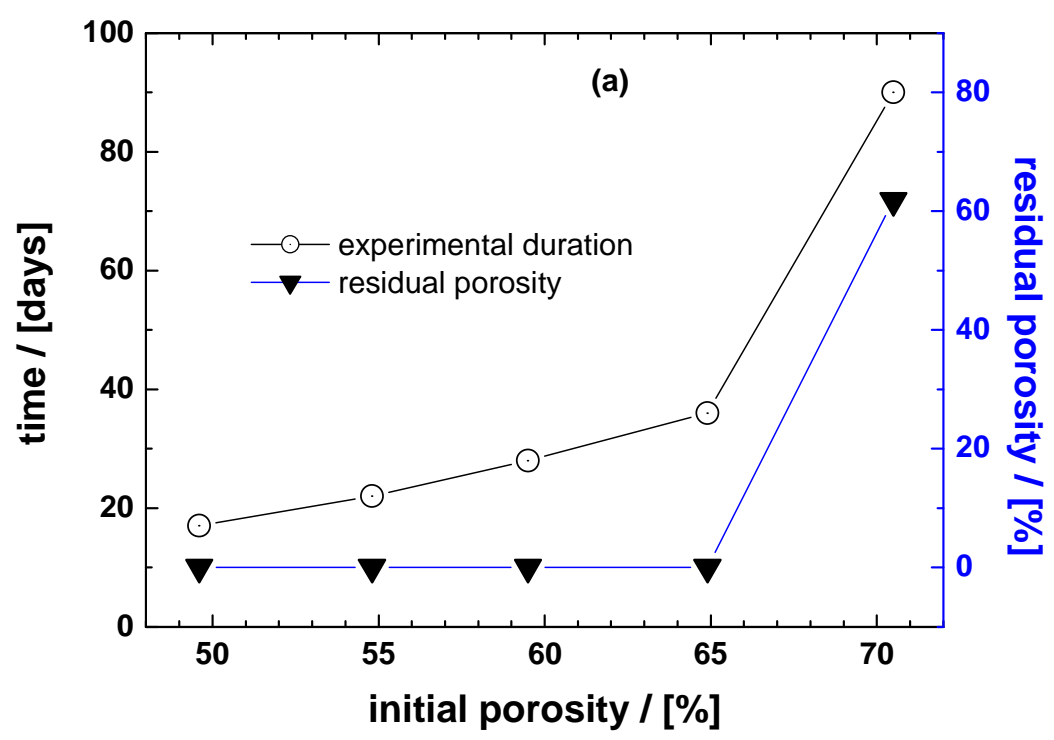

3

4

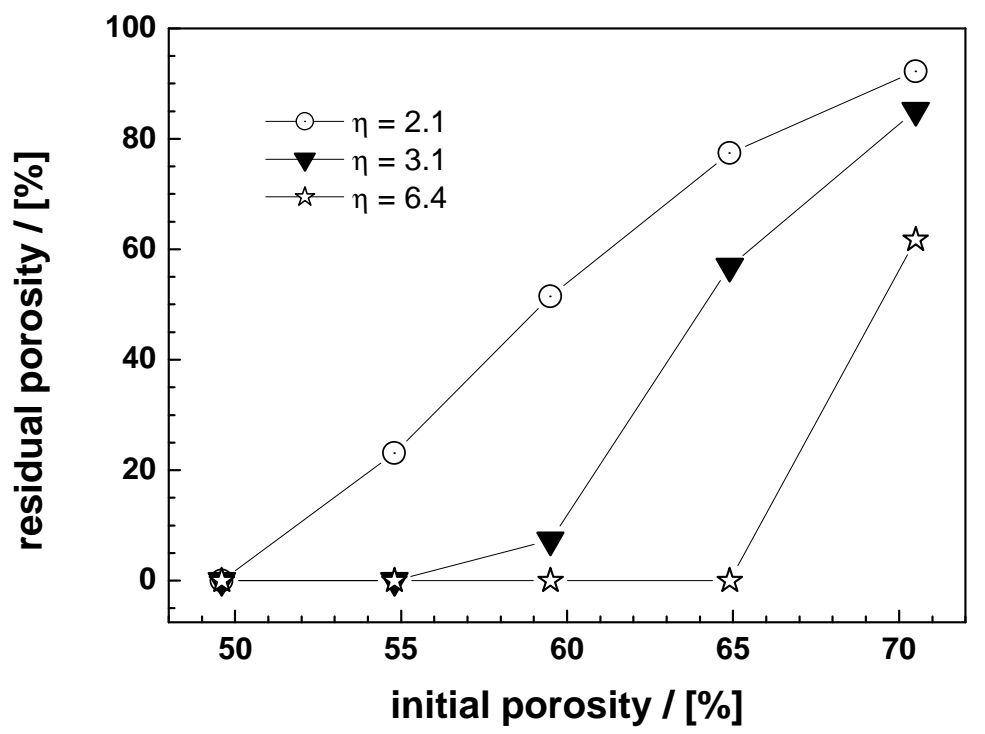

5

6

7

8 


\section{$1 \quad$ Figure captions}

3 Figure 1: Schematic diagram of the experimental design. Used materials were (i) $\mathrm{Fe}^{0}$ (0 or $200 \mathrm{~g}$ ), 4 (ii) pumice ( 0 to $270 \mathrm{~g}$ ), and (iii) quartz gravel (10 $\mathrm{cm}$ at the inlet and balance to fill the column at 5 the outlet).

6 Figure 2: Time-dependant evolution of the $\mathrm{pH}$ value of column effluent. The lines are not fitting

7 functions, they simply connect points to facilitate visualization.

8 Figure 3: Time-dependant evolution of the iron concentration of column effluent for a) all 9 experimental duration and b) the first 50 days. The lines are not fitting functions, they simply 10 connect points to facilitate visualization.

11 Figure 4: Influence of the Fe:pumice volumetric ratio on the removal efficiency of $\mathrm{Cu}^{\mathrm{II}}, \mathrm{Ni}^{\mathrm{II}}$ and $\mathrm{Zn}^{\mathrm{II}}$ as 12 reflected by the Es $(\mathrm{mg} / \mathrm{g})$ values. The lines are not fitting functions, they simply connect points to 13 facilitate visualization.

14 Figure 5: Magnitude of $\mathrm{Cu}, \mathrm{Fe}, \mathrm{Ni}$ and $\mathrm{Zn}$ release from the column with $10 \% \mathrm{Fe}^{0}$. The lines are not fitting 15 functions, they simply connect points to facilitate visualization.

16 Figure 6: (a) Comparison of the initial porosity and the specific efficiency (Es value for $\mathrm{Zn}$ ) as 17 influenced by the Fe:pumice volumetric ratio, (b) Time-dependant evolution of the hydraulic 18 conductivity in all six systems. The lines are not fitting functions, they simply connect points to 19 facilitate visualization.

20 Figure 7: (a) Time-dependant evolution of the residual porosity in all six systems and (b) residual 21 porosity $\Phi(\mathrm{t}) / \Phi_{0}$ for three values of the expansion coefficient $\eta$. The residual porosity is $\Phi(\mathrm{t}) / \Phi_{0}=0$ 22 for systems with clogging before $\mathrm{Fe}^{0}$ depletion and $\Phi(\mathrm{t}) / \Phi_{0} \neq 0$ at $\mathrm{Fe}^{0}$ depletion. The lines are not 23 fitting functions, they simply connect points to facilitate visualization. 
1 Supplementary Information: Material characterization

2

14 SI1 Material characterization

\section{SI1 Material characterization}

\section{(1)} 1

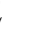

\section{Improving the sustainability of granular iron/pumice systems for water treatment}

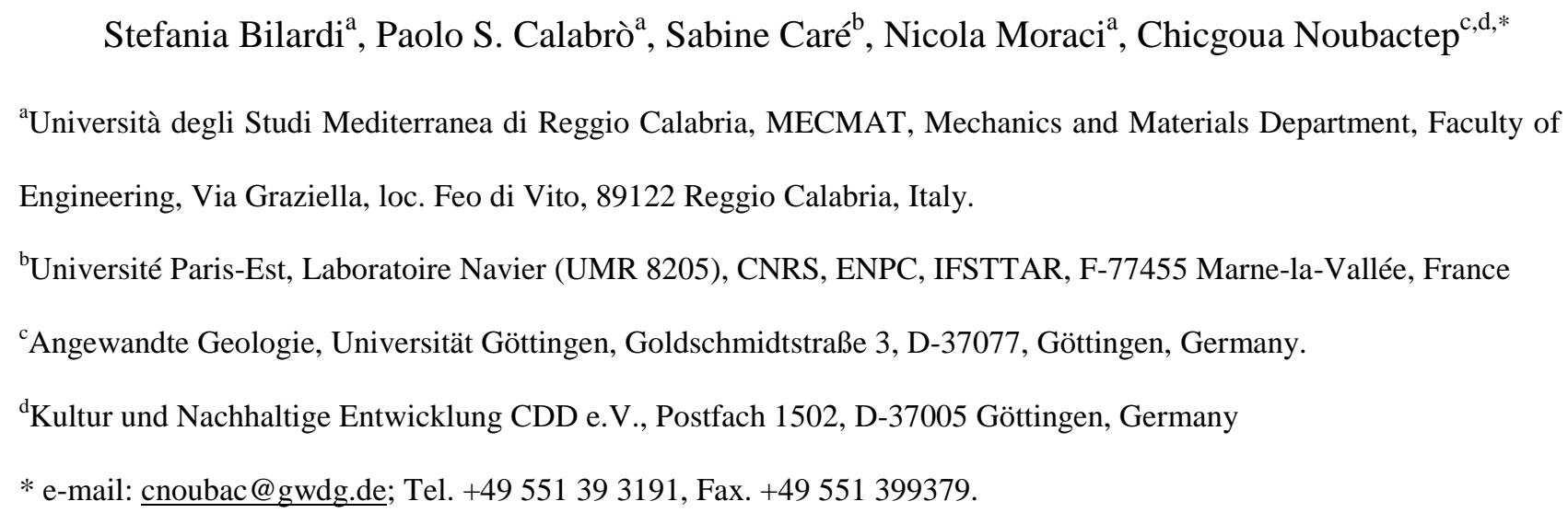

\section{Content}

Table SI1: Composition and experimental duration of the studied columns.

Table SI2: Characteristics of $\mathrm{Fe}^{0}$ and pumice particles tested by MIP.

Figure SI1: SEM images of the $\mathrm{Fe}^{0}$ and pumice particles.

8 Figure SI2 : Grain size distributions of $\mathrm{Fe}^{0}$ and pumice.

9 Figure SI3: Cumulative volume intruded and pore size distribution of the pumice particles.

\footnotetext{
* Corresponding author: Tel. +49 55139 3191, Fax. +49 551 399379; E-mail: cnoubac@ gwdg.de.
} 


\section{SI Material characterization}

\section{SI1 Experimental Section}

3 The microstructure of used $\mathrm{Fe}^{0}$ and pumice was characterized using mercury intrusion porosimetry

4 (MIP) measurements and by scanning electron microscopy (SEM) observations.

5 Moreover grain size distribution and the geotechnical parameters (i.e. coefficient of uniformity and

6 mean grain size) derived from it have been determined.

\section{SI1.1 MIP}

8 MIP is performed by injecting mercury into a desaturated porous material. The in-pore invasion

9 process is supposed to be governed by the Washburn-Laplace equation in which the size of intruded

10 pore accessed, assimilated to cylindrical pores are inversely proportional to the applied pressure 11 according to Eq. 5 (Washburn, 1921):

$$
P=-\frac{2 \gamma \cos \theta}{R_{p}}
$$

13 where $P$ is the mercury injection pressure $(\mathrm{Pa}), \gamma$ is the surface tension of mercury $(0.485 \mathrm{~N} / \mathrm{m}), \theta$ is

14 the contact angle between solid and mercury $\left(\theta=130^{\circ}\right)$ and $R_{p}$ is the pore access radius for 15 cylindrical pores (m). MIP measurements have been carried out using a Micromeritics instrument 16 apparatus type (AutoPore IV 9500). The instrument is capable of a minimum intruding pressure of $17 \quad 3.4 \mathrm{kPa}$ and a maximum pressure of $227 \mathrm{MPa}$, so that the pore radius ranges from $2.7 \mathrm{~nm}$ to 180 $18 \mu \mathrm{m}$.

19 For pumice particles the measured pore data allow determining the inter-particular and intra20 particular porosities of the pumice particles, the apparent specific weight $\rho_{\text {as }}$ (defined as the ratio of 21 the mass and the apparent volume of the pumice particles) and the specific weight $\rho_{\mathrm{s}}$ (defined as the ratio of the mass and the volume of the solid phase of the pumice particles). 


\section{$1 \quad$ SI1.2 SEM}

2 During SEM (Hitachi, type: s3400N) observations, secondary electron mode was used. Pumice 3 particles were coated with carbon. The observations enable a characterization of the morphology of

4 both materials and of the inner pore structure of pumice.

\section{SI2 Results and Discussion}

\section{SI2.1 SEM Observations of $\mathrm{Fe}^{\mathbf{0}}$ and pumice particles}

7 SEM images detailing the microstructures of, respectively, $\mathrm{Fe}^{0}$ and pumice particles are shown in

8 Fig. SI1. These observations show that the $\mathrm{Fe}^{0}$ and pumice particles are irregular. It can be observed 9 that the pumice particles (grains) are porous with oval shaped and fibrous cavities (or pores). The 10 diameter of these cavities at the surface is lower than about $40 \mu \mathrm{m}$ (radius $20 \mu \mathrm{m}$ ).

\section{SI2.2 MIP measurements of pumice particles}

13 As shown in Fig. SI2, where for graphical convenience the pore size distribution is as usual

14 expressed as $\frac{\mathrm{d} V_{i}}{\mathrm{~d}(\log r)}(\log r)$ where $\mathrm{V}_{\mathrm{i}}$ is the volume intruded by mercury and $\mathrm{R}$ is the pore 15 equivalent radius, pumice exhibits a well defined peak around $70 \mu \mathrm{m}$ and pores with equivalent radius inferior to $20 \mu \mathrm{m}$. According to the SEM observations, these results show that the pores with radius inferior to $20 \mu \mathrm{m}$ can be attributed to the inner porosity of the pumice particles, so that the pores with equivalent radius superior to $20 \mu \mathrm{m}$ can be attributed to the inter-particular porosity. The total porosity of the pumice medium $\Phi_{0}(\%)$ in the conditions used in MIP tests, is defined as:

$$
\Phi_{0}=\mathrm{V}_{\text {mercury intruded }} * \mathrm{M} / \mathrm{V}
$$

21 Where $\mathrm{V}_{\text {mercury intruded }}$ is the total intrusion volume $(\mathrm{mL} / \mathrm{g}), \mathrm{M}$ the mass of pumice $(\mathrm{g})$ and $\mathrm{V}$ the volume of the pumice medium $(\mathrm{mL})$.

The volume of the inter-particular volume $\Phi_{\text {inter }}(\%)$ is given by:

$$
\Phi_{\text {inter }}=\mathrm{V}_{\mathrm{R}>20 \mu \mathrm{m}} / \mathrm{V}
$$


1 Where $V_{R>20 \mu m}(m L)$ is the volume of intruded mercury in pores with radius superior to $20 \mu \mathrm{m}$.

2 It can be noticed that the compactness $\mathrm{C}_{\text {pumice }}(-)$ of the pumice particles, defined as the ratio of the 3 apparent volume of the particles to the total packing volume ( $\mathrm{V}=$ volume of the medium), is given 4 by:

$$
\mathrm{C}_{\text {pumice }}=1-\Phi_{\text {inter }}
$$

6 Furthermore, the volume of the intra-particular $\varphi_{\mathrm{pp}}$ is given by:

$$
\varphi_{\mathrm{pp}=}=\mathrm{V}_{\mathrm{R}<40 \mu \mathrm{m}} / \mathrm{V} / \mathrm{C}_{\text {pumice }}
$$

8 Where $\mathrm{V}_{\mathrm{R}<20 \mu \mathrm{m}}(\mathrm{mL})$ is the volume of intruded mercury in pores with radius inferior to $20 \mu \mathrm{m}$.

9 The results are given in Tab. SI2. The total porosity of the pumice medium has been estimated to be $1073.3 \%$ and the inner porosity of the pumice to be $41.0 \%$.

\section{SI2.3 Grain size distributions of $\mathrm{Fe}^{\mathbf{0}}$ and pumice particles}

13 The grain size distributions of $\mathrm{Fe}^{0}$ and pumice particles are shown in Fig. SI3.

14 The main geotechnical parameters derived by the grain size distributions are the coefficient of 15 uniformity $\mathrm{U}=\mathrm{d}_{60} / \mathrm{d}_{10}$ (i.e. ratio between the diameters corresponding to 60 and $10 \%$ finer in the 16 grain size distribution) and the mean grain size $\mathrm{d}_{50}$ (i.e. the diameters corresponding to $50 \%$ finer in 17 the grain size distribution).

18 The mean grain size $\left(\mathrm{d}_{50}\right)$ is about $0.5 \mathrm{~mm}$ and $0.3 \mathrm{~mm}$ for ZVI and Pumice respectively, their 19 coefficients of uniformity (U) are, respectively 2 and 1.4 and therefore both materials are 20 characterised by a uniform grain size distribution.

\section{SI2.4 Porosity of the columns}

23 Under the hypothesis that the relative density (packing) of granular mixtures are the same in the 24 columns and in the MIP tests, the estimated porosity of the reactive zone can be given for systems 25 A through E (Tab. 1, main text) according to: 


$$
\Phi_{0}=\Phi_{\text {inter }}+\varphi_{\mathrm{pp}} \cdot \mathrm{f}_{\mathrm{pp}}
$$

2 where $\mathrm{f}_{\mathrm{pp}}(-)$ is the pumice particle volume fraction determined by $\mathrm{f}_{\mathrm{pp}}=\mathrm{V}_{\mathrm{pp}} / \mathrm{V}$ with $\mathrm{V}_{\mathrm{pp}}$ the volume 3 of the pumice particles and the $\mathrm{V}$ the volume of the reactive zone.

\section{References}

6 Washburn E.W., 1921. The dynamics of capillary flow, Phys. Rev. 17, 273-283.

7

8 
1 Table SI1: Composition and experimental duration of the studied columns. *-marked systems were stopped because of excessive permeability loss.

3

\begin{tabular}{ccc}
\hline System & $\begin{array}{c}\text { Composition } \\
\left(\mathrm{Fe}^{0}: \text { pumice }\right)\end{array}$ & $\begin{array}{c}\text { Duration } \\
(\text { day })\end{array}$ \\
\hline A & $0: 100$ & 45 \\
B & $10: 90$ & 90 \\
C & $25: 75$ & $36^{*}$ \\
D & $50: 50$ & $28^{*}$ \\
E & $75: 25$ & $22^{*}$ \\
F & $100: 0$ & $17^{*}$
\end{tabular}

4

5 
1 Table SI2: Characteristics of $\mathrm{Fe}^{0}$ and pumice particles tested by MIP.

2

\begin{tabular}{lcc}
\hline & $\mathrm{Fe}^{0}$ & Pumice \\
\hline Specific weight $\rho_{\mathrm{s}}\left(\mathrm{g} / \mathrm{cm}^{3}\right)$ & 7.78 & 1.92 \\
Apparent specific weight $\rho_{\mathrm{as}}\left(\mathrm{g} / \mathrm{cm}^{3}\right)$ & 7.78 & 1.14 \\
Compactness C (-) & 0.51 & 0.45 \\
Inter particular porosity $\Phi_{\text {inter }}(\%)$ & 49.6 & 54.8 \\
Intra particular porosity $\varphi_{\mathrm{pp}}(\%)$ & - & 41.0 \\
Porosity $\Phi_{0}(\%)$ & 49.6 & 73.3 \\
\hline
\end{tabular}

3

4 
1 Figure SI1: SEM images of the $\mathrm{Fe}^{0}$ particles (A) and of the pumice particles (B).
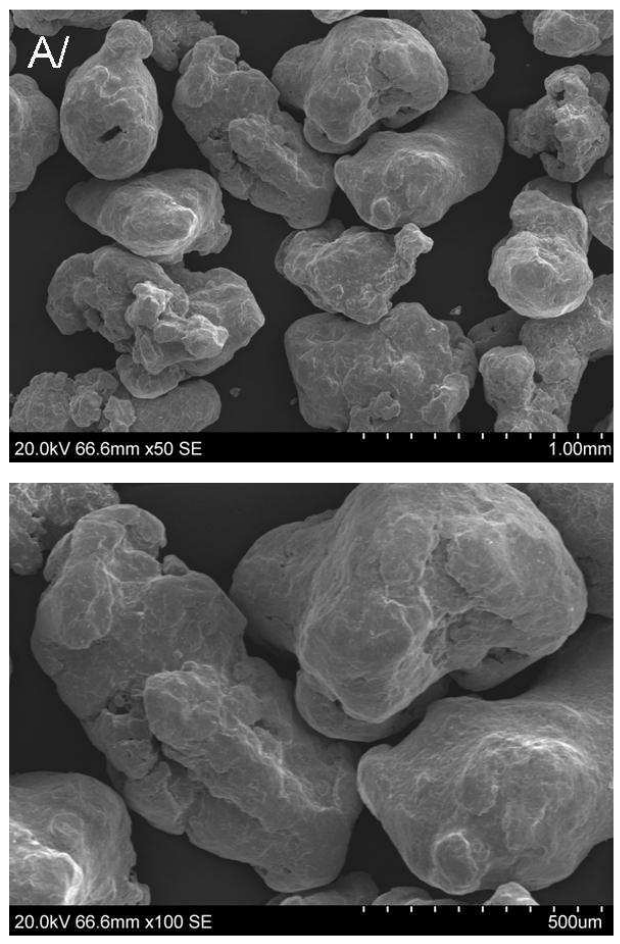
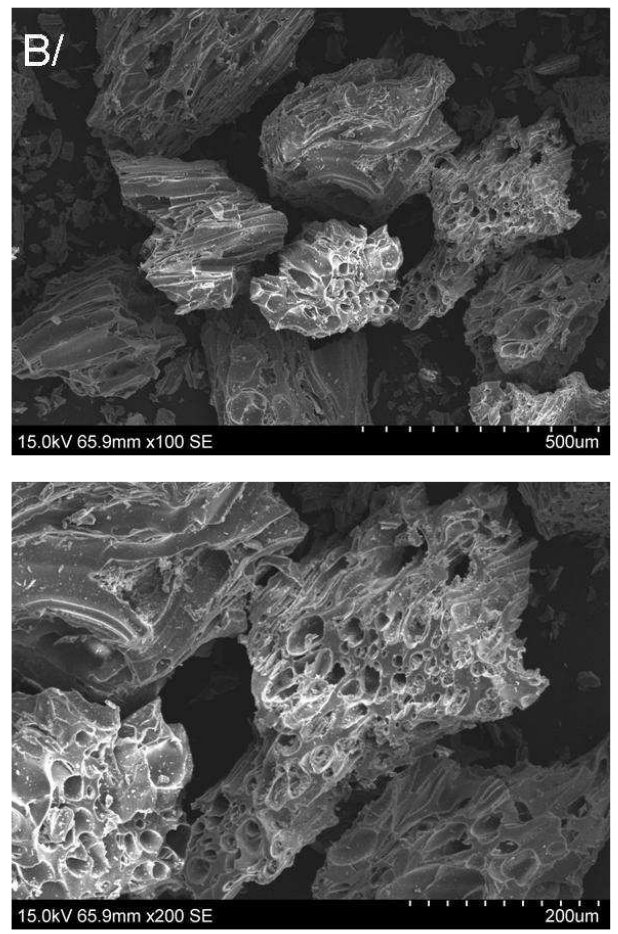
1 Figure SI2: Cumulative volume intruded $(\mathrm{mL} / \mathrm{g})$ and pore size distribution of the pumice particles.

2 Two types of porosity are observed: inter particular porosity $\Phi_{\text {inter }}(\mathrm{R}>20 \mu \mathrm{m})$ and intra particular 3 porosity $\varphi_{\mathrm{pp}}(\mathrm{R}<20 \mu \mathrm{m})$.

4

5

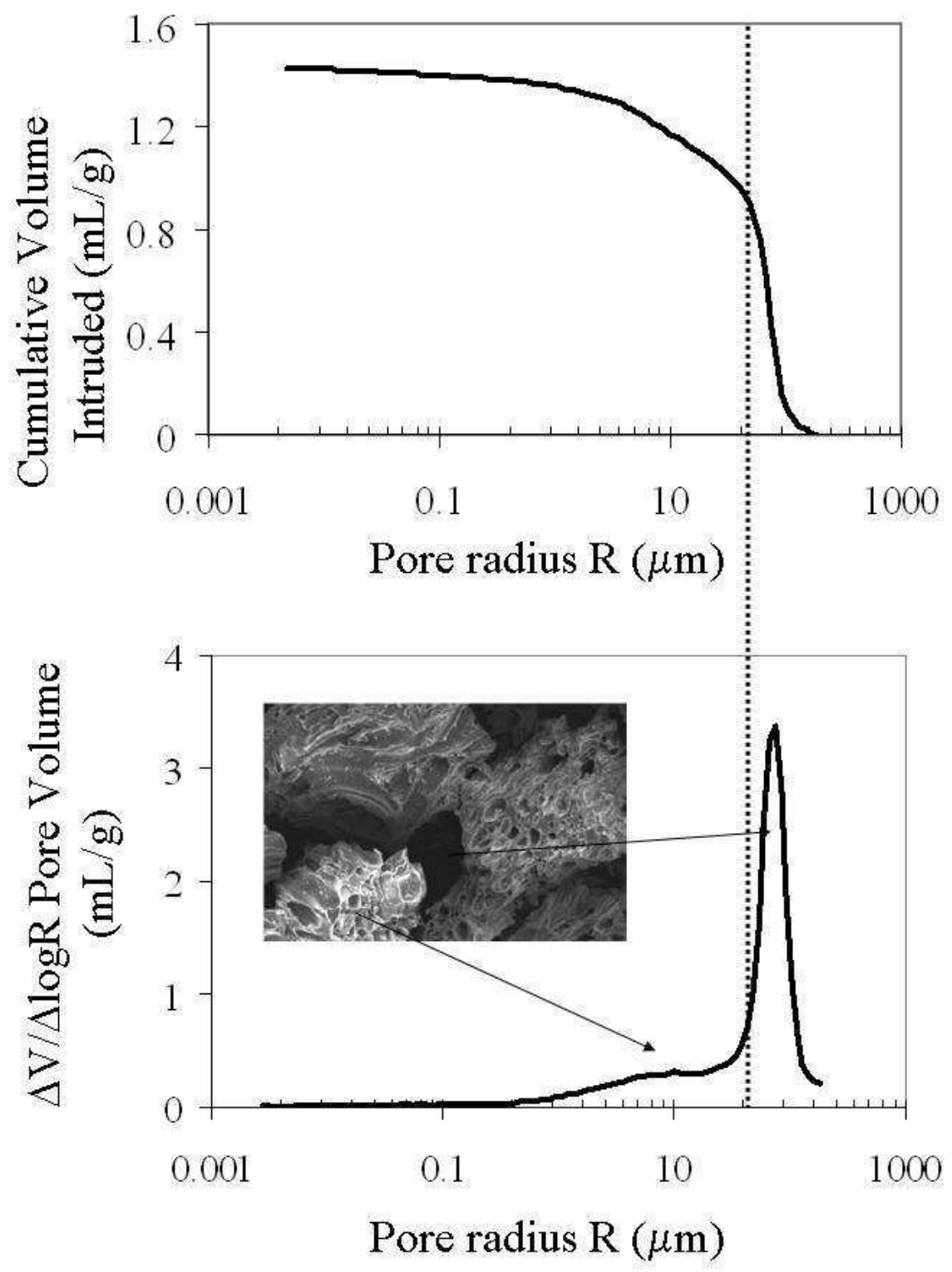


1 Figure SI3: Grain size distributions of used materials: $\mathrm{Fe}^{0}$ (a) and pumice (b).

2
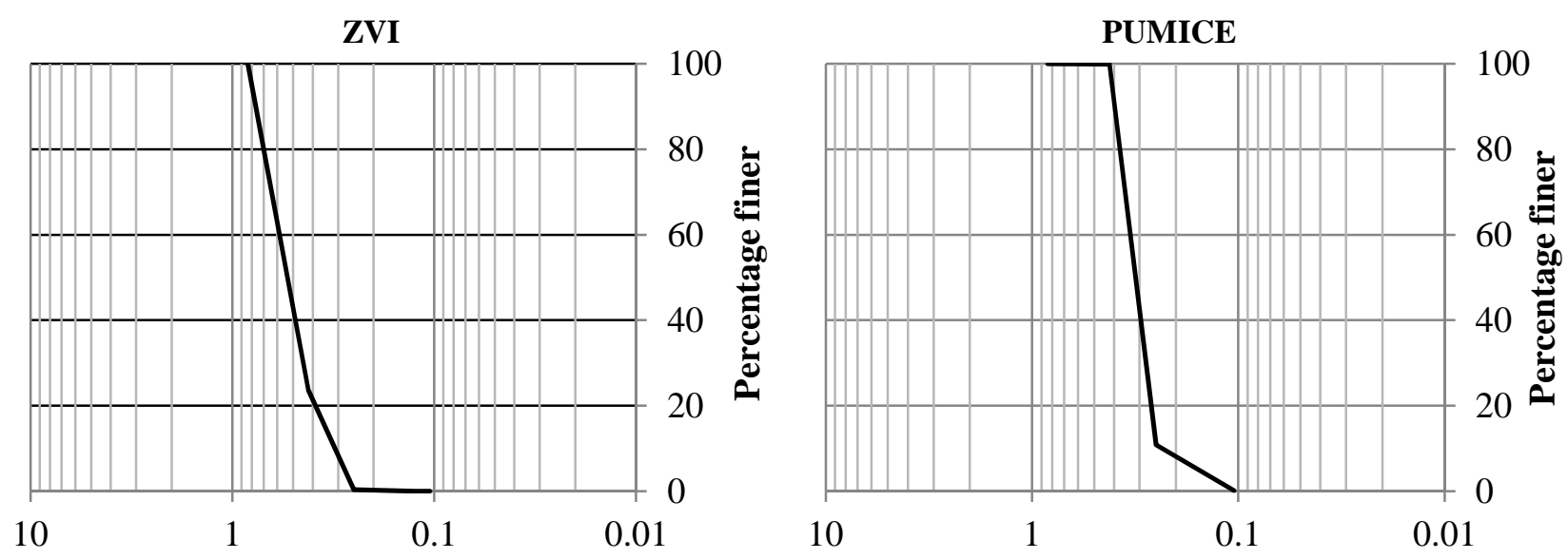

a)

Log size (mm)

b)

Log size (mm)

4 